\title{
Differential Excitability and Modulation of Striatal Medium Spiny Neuron Dendrites
}

\author{
Michelle Day, David Wokosin, Joshua L. Plotkin, Xinyoung Tian, and D. James Surmeier \\ Department of Physiology, Feinberg School of Medicine, Northwestern University, Chicago, Illinois 60611
}

The loss of striatal dopamine (DA) in Parkinson's disease (PD) models triggers a cell-type-specific reduction in the density of dendritic spines in $\mathrm{D}_{2}$ receptor-expressing striatopallidal medium spiny neurons $\left(\mathrm{D}_{2} \mathrm{MSNs}\right)$. How the intrinsic properties of MSN dendrites, where the vast majority of DA receptors are found, contribute to this adaptation is not clear. To address this question, two-photon laser scanning microscopy (2PLSM) was performed in patch-clamped mouse MSNs identified in striatal slices by expression of green fluorescent protein (eGFP) controlled by DA receptor promoters. These studies revealed that single backpropagating action potentials (bAPs) produced more reliable elevations in cytosolic $\mathrm{Ca}^{2+}$ concentration at distal dendritic locations in $\mathrm{D}_{2}$ MSNs than at similar locations in $\mathrm{D}_{1}$ receptorexpressing striatonigral MSNs ( $\mathrm{D}_{1}$ MSNs). In both cell types, the dendritic $\mathrm{Ca}^{2+}$ entry elicited by bAPs was enhanced by pharmacological blockade of Kv4, but not $\mathrm{Kv}_{1} \mathrm{~K}^{+}$channels. Local application of DA depressed dendritic bAP-evoked $\mathrm{Ca}^{2+}$ transients, whereas application of ACh increased these $\mathrm{Ca}^{2+}$ transients in $\mathrm{D}_{2}$ MSNs, but not in $\mathrm{D}_{1}$ MSNs. After DA depletion, bAP-evoked $\mathrm{Ca}^{2+}$ transients were enhanced in distal dendrites and spines in $\mathrm{D}_{2}$ MSNs. Together, these results suggest that normally $\mathrm{D}_{2}$ MSN dendrites are more excitable than those of $\mathrm{D}_{1}$ MSNs and that DA depletion exaggerates this asymmetry, potentially contributing to adaptations in PD models.

Key words: striatum; medium spiny neuron; glutamatergic synapse; dopamine; acetylcholine; Parkinson's disease; potassium channels

\section{Introduction}

The principal neuronal cell type in the striatum is the medium spiny neuron (MSN). MSNs can be divided into two approximately equal groups based on axonal projections, peptide expression, and expression of dopamine (DA) receptors (Albin et al., 1989; Gerfen et al., 1998). MSNs that preferentially project axons to the substantia nigra express $\mathrm{D}_{1} \mathrm{DA}$ receptors whereas those that preferentially project to the external segment of the globus pallidus express $\mathrm{D}_{2}$ DA receptors. Each of these MSN populations can be reliably sampled in bacterial artificial chromosome (BAC) transgenic mice in which green fluorescent protein (GFP) is expressed under control of $\mathrm{D}_{1}$ receptor or $\mathrm{D}_{2}$ receptor promoter regions (Gong et al., 2003; Day et al., 2006).

Work with these mice shows that induction of a state mimicking Parkinson's disease (PD) leads to a rapid and selective loss of spines and glutamatergic synapses in $\mathrm{D}_{2}$ receptor-expressing striatopallidal MSNs, but not in $\mathrm{D}_{1}$ receptor-expressing striatonigral MSNs (Day et al., 2006). Although dendritic $\mathrm{Ca}^{2+}$ entry through depolarization-activated Cav1.3 $\mathrm{Ca}^{2+}$ channels is necessary for the loss of spines and synapses, it is not clear why DA depletion should increase the activity of these channels. What is known is that the loss of inhibitory $\mathrm{D}_{2}$ receptor signaling in $\mathrm{PD}$

Received Sept. 24, 2008; accepted Sept. 29, 2008.

This work was supported by National Institutes of Health (NIH) Grant NS34696 (D.J.S.), the Picower Foundation (D.J.S.), and NIH Grant MH76164 (M.D.). We thank Drs. John Dempster, Philip Hockberger, Qing Ruan, Joshua Held, Karen Saporito, and Sasha Ulrich for excellent technical assistance, and Dr. Nelson Spruston for careful reading of this manuscript.

Correspondence should be addressed to D. James Surmeier, Department of Physiology, Feinberg School of Medicine, Northwestern University, 303 East Chicago Avenue, Chicago, IL60611. E-mail: j-surmeier@northwestern.edu. DOI:10.1523/JNEUROSCI.1840-08.2008

Copyright $\odot 2008$ Society for Neuroscience $\quad$ 0270-6474/08/2811603-12\$15.00/0 models selectively increases spike generation in striatopallidal MSNs (Mallet et al., 2006). In addition, $\mathrm{D}_{2}$ receptors also negatively couple to voltage dependent Cav1.3 $\mathrm{Ca}^{2+}$ channels in striatopallidal MSNs (Olson et al., 2005), suggesting that the combination of these effects might lead to increased dendritic $\mathrm{Ca}^{2+}$ entry in PD models. However, it is far from clear whether spikes initiated in the axon initial segment back-propagate any significant distance into the dendritic trees of MSNs that normally reside very near the $\mathrm{K}^{+}$equilibrium potential (approximately -80 mV), far from spike threshold (Wilson and Kawaguchi, 1996). Work using two-photon laser scanning microscopy (2PLSM) in conjunction with patch-clamp electrophysiology has shown that proximal dendrites and spines ( $\sim 40-50 \mu \mathrm{m}$ from the soma) of MSNs are depolarized enough by somatic spikes that voltagedependent $\mathrm{Ca}^{2+}$ channels are opened (Carter and Sabatini, 2004). However, it is not known whether backpropagation of action potentials (bAPs) occurs in more distal dendritic regions, where most of the spine and synapse loss occurs after DA depletion. Nor is it known whether bAP invasion of the dendrites differs in $\mathrm{D}_{1}$ and $\mathrm{D}_{2}$ MSNs.

To answer these questions, 2PLSM and patch-clamp electrophysiology were used to study $D_{1}$ and $D_{2}$ MSNs in brain slices from BAC transgenic mice. Neurons were loaded with a $\mathrm{Ca}^{2+}$ sensitive dye to provide a direct measure of dendritic $\mathrm{Ca}^{2+}$ influx and an indirect measure of dendritic membrane potential (Carter and Sabatini, 2004). Our study suggests that normally, bAPs invade more distal dendritic regions of $\mathrm{D}_{2}$ MSNs than $\mathrm{D}_{1}$ MSNs. This invasion is controlled not only by voltage-dependent $\mathrm{Na}^{+}$ channels but also by $\mathrm{Kv} 4 \mathrm{~K}^{+}$channels. More importantly from the standpoint of understanding the adaptations in PD models, $\mathrm{DA}$ and acetylcholine (ACh) potently modulate the bAP-evoked 
dendritic $\mathrm{Ca}^{2+}$ transient in $\mathrm{D}_{2}$ MSNs, but not in $\mathrm{D}_{1}$ MSNs, providing a mechanism by which DA depletion could enhance the electrical coupling between somatic and dendritic regions and trigger spine loss. Simulations suggest that spine loss itself further increases dendritic excitability, creating the potential for progressive loss of dendritic synapses in $\mathrm{D}_{2}$ MSNs and their functional linkage with cortical structures.

\section{Materials and Methods}

Brain slice preparation. Parasagittal brain slices $(275 \mu \mathrm{m})$ were obtained from 17 - to 25 -d-old $\mathrm{BAC} \mathrm{D}_{1}$ or $\mathrm{BAC}_{2}$ transgenic mice following procedures approved by the Northwestern University Animal Care and Use Committee and guidelines of the National Institutes of Health. The mice were anesthetized with isoflurane (Baxter) and decapitated. Brains were rapidly removed and sectioned in oxygenated, ice-cold, artificial CSF (ACSF) using a Leica VT1000S vibratome (Leica Microsystems). The ACSF contained the following (in $\mathrm{mM}$ ): $124 \mathrm{NaCl}, 3 \mathrm{KCl}, 2 \mathrm{CaCl}_{2}, 1$ $\mathrm{MgCl}_{2}, 26 \mathrm{NaHCO}_{3}, 1 \mathrm{NaH}_{2} \mathrm{PO}_{4}$, and $10 \mathrm{D}-(+)$-glucose. Unless otherwise noted, all chemicals and reagents were obtained from Sigma/RBI. The slices were transferred to a holding chamber where they were incubated in ACSF at $35^{\circ} \mathrm{C}$ for $1 \mathrm{~h}$, after which they were stored at room temperature until whole-cell recording experiments $(1-5 \mathrm{~h})$. The external ACSF solutions were bubbled with $95 \% \mathrm{O}_{2} / 5 \% \mathrm{CO}_{2}$ at all times to maintain oxygenation and a $\mathrm{pH} \sim 7.4$. The solutions were periodically checked and adjusted to maintain physiological osmolality (300 $\mathrm{mOsm} / \mathrm{L})$.

2PLSM. $\mathrm{D}_{1}\left(\mathrm{BAC}_{1}\right)$ or $\mathrm{D}_{2}$ (BAC $\mathrm{D}_{2}$ ) receptor-expressing MSNs in $275-\mu \mathrm{m}$-thick corticostriatal slices were identified by somatic eGFP twophoton excited fluorescence using an Ultima Laser Scanning Microscope (2PLSM) system (Prairie Technologies). A DODT contrast detector system was used to provide a bright-field transmission image in registration with the fluorescent images. The green GFP signals $(490-560 \mathrm{~nm})$ were acquired using $810 \mathrm{~nm}$ excitation (Verdi/Mira laser: Coherent Laser Group). MSNs were patched using video microscopy with a Hitachi CCD camera (model KP-M2RN) and an Olympus UIS1 60×/0.9 NA waterdipping lens. Patch electrodes were made by pulling BF150-86-10 glass on a P-97 Flaming/Brown micropipette puller (Sutter Instrument). The pipette solution contained the following (in $\mathrm{mm}$ ): $135 \mathrm{KMeSO}_{4}$ (ICN Biomedicals), $5 \mathrm{KCl}, 10$ HEPES, $2 \mathrm{MgATP}, 0.2 \mathrm{Na}_{2} \mathrm{GTP}, 10$ phosphocreatine, and 0.1 spermine, $\mathrm{pH}=7.25-7.3$ with $\mathrm{KOH}, 270 \mathrm{mOsm} / \mathrm{L}$. In some experiments, the pipette solution contained the following (in $\mathrm{mM}$ ): $120 \mathrm{CsMeSO}_{3}, 15 \mathrm{CsCl}, 8 \mathrm{NaCl}, 10$ HEPES, 3 MgATP, $0.3 \mathrm{NaGTP}, 10$ TEA, 5 Qx-314. As measured in the bath, the pipette resistance was $\sim 4$ $\mathrm{M} \Omega$. High-resistance $(>1 \mathrm{G} \Omega$ ) seals were formed in voltage-clamp mode on somata. After patch rupture, the series resistance decreased to $10-15 \mathrm{M} \Omega$. The inclusion of Alexa $568(50 \mu \mathrm{M})$ allowed visualization of cell bodies, dendrites, and spines. After patch rupture, the internal solution was allowed to equilibrate for 15-20 min before imaging. Somata were voltage clamped at $-80 \mathrm{mV}$ and monitored. High-magnification maximum projection images of dendrite segments $(45-150 \mu \mathrm{m})$ were acquired with $0.08 \mu \mathrm{m}^{2}$ pixels with $10 \mu$ s dwell time; $10-20$ images were taken with $0.5 \mu \mathrm{m}$ focal steps. Maximum projection images of the soma and dendrites were acquired with $0.36 \mu \mathrm{m}^{2}$ pixels with $10 \mu$ s pixel dwell time; $\sim 80$ images were taken with $1 \mu \mathrm{m}$ focal steps. Dendrites that were largely limited to a single optical plane ( $\leq 10 \mu \mathrm{m} Z$ variance) were selected for calculating the bAP-evoked $\mathrm{Ca}^{2+}$ signal decrement over distance.

Electrophysiology and $\mathrm{Ca}^{2+}$ imaging. Whole-cell current-clamp recordings were obtained using standard techniques. Slices were transferred to a submersion-style recording chamber mounted on an Olympus BX51-WIF upright, fixed-stage microscope. The slices where continuously perfused with $\sim 1.5 \mathrm{ml} / \mathrm{min}$ ACSF at room temperature. Electrophysiological recordings were obtained with a Multiclamp 700B amplifier (Axon Instruments) and then digitized with the scanning computer (PCI MIO-16E-4, National Instruments). The stimulation, display, and analysis software was a custom-written shareware package, WinFluor (John Dempster, Strathclyde University, Glasgow, Scotland, UK). WinFluor automated and synchronized the two-photon excited fluores- cence with the electrophysiological stimulation. Single bAPs were generated by injecting current pulses $(2 \mathrm{nA}, 2 \mathrm{~ms})$ at $5 \mathrm{~s}$ intervals. In some cases, a $1 \mathrm{~s}$ train of current pulses ( $1 \mathrm{nA}, 2 \mathrm{~ms})$ was delivered at $10 \mathrm{~Hz}$. Rheobase was determined using a $1 \mathrm{~s}$ current step. Drugs were either bath applied by dissolving them in the external ACSF or focally applied using pressure ejection through a micropipette filled with both the drug and Alexa 568 to aid the placement of the puffer pipette and to visualize the "puff." These compounds were dissolved in HEPES-buffers ACSF ( $\mathrm{pH}=7.3-4)$ and the pipette positioned $10-20 \mu \mathrm{m}$ from the imaged dendrite/spine. $\alpha$-Dendrotoxin (Alomone Labs) was dissolved in ACSF containing $0.1 \%$ BSA.

For 2PLSM imaging of $\mathrm{Ca}^{2+}$ transients, the neurons were filled via the patch pipette with the $\mathrm{Ca}^{2+}$ indicator Fluo-4 $(200 \mu \mathrm{M})$. At this concentration, Fluo-4 gave a reliable measure of alterations in dendritic $\mathrm{Ca}^{2+}$ concentration in response to single somatic spikes, as well as short bursts of spikes. To verify that the dye was not saturated, $\mathrm{K}^{+}$channel blockers $\left(\mathrm{Cs}^{+}, 4-\mathrm{AP}\right)$ were used to increase the dendritic depolarization; in both cases, the spike-induced fluorescence increased 3- to 10-fold, confirming that the dye was not saturated. Green fluorescent line-scan signals were acquired (as described above) at $6 \mathrm{~ms}$ per line and 512 pixels per line with $0.08 \mu \mathrm{m}$ pixels and $10 \mu$ s pixel dwell time. The laser-scanned images were acquired with $810 \mathrm{~nm}$ light pulsed at $90 \mathrm{MHz}$ ( $\sim 250 \mathrm{fs}$ pulse duration). Power attenuation was achieved with two Pockels cells electro-optic modulators (models 350-80 and 350-50, Con Optics). The two cells were aligned in series to provide an enhanced modulation range for fine control of the excitation dose ( $0.1 \%$ steps over four decades). The line scan was started $200 \mathrm{~ms}$ before the stimulation protocol and continued $4 \mathrm{~s}$ after the stimulation to obtain the background fluorescence and to record the decay of the optical signal after stimulation. To reduce photodamage and photobleaching, the laser was fully attenuated using the second Pockels cell at all times during the scan except for the $500 \mathrm{~ms}$ period directly flanking the bAP.

Cell culture and immunofluorescence. Corticostriatal cocultures were prepared to promote normal dendritic development and spine growth in medium spiny neurons (Segal et al., 2003). Striatal tissue was isolated from 1- to 2-d-old BAC D2 mice. Cortices were dissected from 18- to 19-d-old C57BL/6 mouse embryos. Tissues were digested with papain (Worthington Biochemical Corporation) and dissociated. Striatal and cortical cells were mixed at a ratio of 3:1 and plated at a density of $1 \times$ $10^{5} / \mathrm{cm}^{2}$ on $12 \mathrm{~mm}$ coverslips coated with polyethylenimine (Sigma). Coverslips were placed in 24-well plates with Neurobasal A medium (Invitrogen) supplemented with $0.5 \mathrm{~mm}$ glutamine (Invitrogen), $1 \times \mathrm{B} 27$ (Invitrogen), $50 \mathrm{mg} / \mathrm{L}$ penicillin/streptomycin (Invitrogen), $50 \mathrm{ng} / \mathrm{ml}$ BDNF (Sigma), and $30 \mathrm{ng} / \mathrm{ml}$ GDNF (Sigma). After initial plating, onefourth of the medium was exchanged with fresh medium without BDNF and GDNF every 3-4 d.

Twenty-one days after plating, cultures were fixed with $4 \%$ paraformaldehyde in phosphate-buffered saline (PBS, pH 7.4) buffer for $20 \mathrm{~min}$ at room temperature. Fixed cells were incubated in blocking buffer containing $0.2 \%$ Triton X-100, 1\% BSA, 5\% normal goat serum (Jackson ImmunoResearch Laboratories), and $0.01 \%$ sodium azide in PBS for $1 \mathrm{~h}$ at room temperature. Coverslips were then exposed to rabbit anti-GFP antibody (1:3000, Abcam) and mouse anti-Kv4.2 monoclonal antibody (1:500, NeuroMab) in blocking buffer overnight at $4^{\circ} \mathrm{C}$. After a brief wash in PBS, cells were incubated with Alexa 488-conjugated goat antirabbit antibody (1:1000, Invitrogen) and Alexa 555-conjugated goat anti-mouse antibody (1:1000, Invitrogen) for $1 \mathrm{~h}$ at room temperature. After rinsing in PBS for 30 min, coverslips were mounted with Prolong Gold anti-fade reagent (Invitrogen). Image acquisition was performed with a LSM 510 META Laser Scanning Microscope (Zeiss).

Computer simulations. Medium spiny neurons were modeled with NEURON, version 6.0 (Hines and Carnevale, 1997, 2001). The model neuron was constructed of a cylindrical soma $(L=12 \mu \mathrm{m}, D=12 \mu \mathrm{m})$, six dendrites, an axon initial segment (AIS) $(L=10 \mu \mathrm{m}, D=1.4 \mu \mathrm{m})$, and a cylindrical axon consisting a sequence of 5 sections $(L=100 \mu \mathrm{m}$, $D=1 \mu \mathrm{m})$ separated by 4 nodes $(L=1 \mu \mathrm{m}, D=1 \mu \mathrm{m})$. Each dendrite consisted of 1 primary section $(L=10 \mu \mathrm{m}, D=2.25 \mu \mathrm{m}), 2$ secondary sections ( $L=20 \mu \mathrm{m}, D=2.5 \mu \mathrm{m})$, and 4 tertiary sections $(L=180 \mu \mathrm{m}$, $D=0.75 \mu \mathrm{m})$. Axial resistivity was $200 \Omega \cdot \mathrm{cm}$. Membrane capacitance 
was $1 \mu \mathrm{F} / \mathrm{cm}^{2}$. The cell model incorporated biophysically accurate ion channel models describing Na, BK, SK, Kv1, Kv2, Kv4, Kv7 (KCNQ), and Kir2 channels, as well as a $\mathrm{Ca}^{2+}$ buffering system, that were constrained by experimental data (Baranauskas et al., 1999; Tkatch et al., 2000; Baranauskas et al., 2003; Chan et al., 2004; Shen et al., 2005) or acquired from NEURON database mod files from previous simulations (Migliore et al., 1995; Wang et al., 2002; Khaliq et al., 2003) and incorporated into the appropriate compartments. All simulations were done at $23^{\circ} \mathrm{C}$ and with an $E_{\mathrm{Na}}$ of $50 \mathrm{mV}$ and $E_{\mathrm{K}}$ of $-90 \mathrm{mV}$. NEURON mod files providing a complete description of the model are available upon request and will be posted on the NeuronDB web site (http://senselab.med.yale.edu/ neuronDB).

Data analysis. All data points represent a spine, dendrite, or spinedendrite pair from individual cells. Data were visualized and analyzed with custom image-processing shareware software (PicViewer and WinFluor, John Dempster). IGOR Pro (WaveMetrics) was used for data smoothing and statistics. The mean fluorescence as a function of time $[F(t)]$ was the spatial average of 5 adjacent pixels. The basal fluorescence, $F_{\mathrm{o}}$, was average of the first 30 time points in a line scan. The percentage change in $\mathrm{Ca}^{2+}$ signal $\left(\Delta F / F_{\mathrm{o}}\right)$ was defined as the maximum fluorescence change normalized by the basal fluorescence. The acquired fluorescence data were then imported to IGOR, where some traces were smoothed with a binomial Gaussian filter. The statistical significance of small, unmatched samples was determined using a nonparametric Kruskal-Wallis one-way ANOVA. Data are presented in a nonparametric format as box plots with the median shown as a central bar; upper and lower edges of the box split the upper and lower halves of the data in half again (interquartile range); the whiskers span the distribution of data points, except for outliers.

\section{Results}

bAP-evoked $\mathrm{Ca}^{2+}$ transients decrement less in $\mathrm{D}_{2}$ than in $\mathrm{D}_{1}$ MSN dendrites

Striatopallidal $\left(\mathrm{D}_{2}\right)$ or striatonigral $\left(\mathrm{D}_{1}\right)$ MSNs were visually identified using 2PLSM excitation of eGFP as previously described (Day et al., 2006). Somatic whole-cell current recordings were made with electrodes filled with Alexa $568(50 \mu \mathrm{M})$ and Fluo-4 $(200 \mu \mathrm{M})$. The Alexa 568 enabled detailed visualization of distal dendrites and spines, whereas the $\mathrm{Ca}^{2+}$-sensitive indicator Fluo- 4 reported $\mathrm{Ca}^{2+}$ transients induced in these regions by the somatically generated bAPs. After eGFP phenotyping and patching, the internal solution was allowed to equilibrate for $20 \mathrm{~min}$. 2PLSM line scanning was then performed between 45 and 130 $\mu \mathrm{m}$ from the soma (Fig. $1 A, B$ ). Estimates of the $\mathrm{Ca}^{2+}$ transient were generated by eliciting six bAPs (equally spaced at $5 \mathrm{~s}$ intervals), and then averaging the responses. Spacing in this way allowed ample time for the $\mathrm{Ca}^{2+}$ to return to basal levels and remain there for several seconds before the onset on the next bAP in the series. The bAPs were evoked by injecting a $2 \mathrm{~ms}, 2 \mathrm{nA}$ current pulse into the soma (Fig. $1 A$, right panel, $I$ and $V$ traces). To control for photodamage, dendritic processes were only illuminated during a $0.5 \mathrm{~s}$ window that bracketed the initiation of the bAP. Measurements were taken concurrently from a spine and the parent dendrite close to the base of the spine. In all cases, if a $\mathrm{Ca}^{2+}$ transient was detected in the spine, it was also detected in the dendrite. The maximum amplitude of the bAP-evoked $\mathrm{Ca}^{2+}$ transient was determined by calculating $\Delta F / F_{\mathrm{o}}$ for each transient (image panels), averaging the results (black traces), and then fitting the decay phase of data with a single exponential (gray lines) to extrapolate back to the peak of the transient. The key finding in these initial experiments was that in $\mathrm{D}_{1}$ MSNs, single bAPs frequently failed to evoke a detectable $\mathrm{Ca}^{2+}$ transient at dendritic sites $>60 \mu \mathrm{m}$ from the soma (Fig. $1 \mathrm{~A}$ ), whereas in $\mathrm{D}_{2} \mathrm{MSNs}$, dendritic $\mathrm{Ca}^{2+}$ transients were readily detected at this distance and beyond (Fig. $1 B$ ).

To better characterize the disparity in the bAP-evoked $\mathrm{Ca}^{2+}$ transients between the two populations of MSNs, bAP-evoked $\mathrm{Ca}^{2+}$ transients from each cell type were scanned at varying distances from the soma (Fig. 1C,D). Here, the amplitudes of bAPevoked $\mathrm{Ca}^{2+}$ transient from each scan point in each cell type were normalized to the most proximal location scanned and then plotted as a function of distance from the soma ( $n=6$ each). These experiments confirmed differences in somato/dendritic excitability between MSNs, with the $\mathrm{D}_{2}$ MSNs showing less attenuation of bAP-evoked $\mathrm{Ca}^{2+}$ transients in distal spines and dendrites than $\mathrm{D}_{1}$ MSNs. To test the possibility that the loss in bAP response was attributable to declining dendritic $\mathrm{Ca}^{2+}$ channel density, $\mathrm{D}_{1} \mathrm{MSN}$ s were loaded with $\mathrm{Cs}^{+}$(to improve voltage control of distal dendrites) and the somatic membrane briefly stepped to a depolarized potential. In this situation, there was no detectable attenuation of the $\mathrm{Ca}^{2+}$ transient with distance from the soma (Fig. 1D), arguing that the loss of the bAP-evoked $\mathrm{Ca}^{2+}$ transient was not caused by diminished $\mathrm{Ca}^{2+}$ channel density. Further evidence that this phenomenon did not simply reflect diminished $\mathrm{Ca}^{2+}$ channel density in distal dendrites was that strong depolarization (1 s) and trains of APs $(10 \times 10 \mathrm{~Hz})$ consistently evoked $\mathrm{Ca}^{2+}$ transients in distal process of all MSNs tested (supplemental Fig. S1, available at www.jneurosci.org as supplemental material).

Although single bAPs were not propagated efficiently into the distal dendrites of $\mathrm{D}_{1}$ MSNs, bursts of somatic action potentials were able to evoke $\mathrm{Ca}^{2+}$ transients in more distant dendritic regions. Three spike bursts $(50 \mathrm{~Hz})$ delivered at a theta frequency reliably evoked shaft and spine $\mathrm{Ca}^{2+}$ transients in both $\mathrm{D}_{1}$ and $\mathrm{D}_{2}$ MSN dendrites 100-120 $\mu \mathrm{m}$ from the soma (Fig. $1 E$ ). The $\mathrm{Ca}^{2+}$ signals evoked by successive bursts summed in a sublinear manner (Fig. $1 E, F)$. This sublinearity was more pronounced in $\mathrm{D}_{1}$ MSNs than in $\mathrm{D}_{2}$ MSNs (Fig. $1 F$ ). Moreover, consistent with the response to single bAPs, the relative elevation in $\mathrm{Ca}^{2+}$ evoked by somatically generated theta bursts were smaller in amplitude and area in $\mathrm{D}_{1}$ MSNs (Fig. $1 F$ ).

\section{Action potentials are actively propagated into the proximal dendrites of $\mathrm{D}_{2}$ MSNs}

In the dendrites of cortical pyramidal neurons, voltagedependent $\mathrm{Na}^{+}$channels play an important role in actively propagating somatic spikes into dendrites (Spruston et al., 1995; Stuart et al., 1997). Blocking these channels in proximal dendrites by local application of tetrodotoxin (TTX) disrupts backpropagation of action potentials, attenuating the opening of depolarization-activated $\mathrm{Ca}^{2+}$ channels located in distal dendritic regions. To determine whether $\mathrm{Na}^{+}$channels played a similar role in $\mathrm{MSNs}, \mathrm{Na}^{+}$channels were blocked by focally applying TTX $(1 \mu \mathrm{M})$ to dendrites (Fig. 2A). Application of TTX $(1 \mu \mathrm{M})$ to the proximal dendrite between the somatic electrode and the dendritic region being scanned consistently diminished the bAPevoked $\mathrm{Ca}^{2+}$ transient $(n=5)$ (Fig. $\left.2 B\right)$ (control = black trace, TTX $=$ red trace). Dendritic application of TTX had no effect on the somatic spike amplitude. On average, the dendritic fluorescence signal was reduced to $20 \%$ of control by application of TTX to proximal dendrites (Fig. $2 \mathrm{~B}$, box plot). At more distal locations (70-100 $\mu \mathrm{m}$ from the soma), TTX application had little or no effect on the bAP-associated $\mathrm{Ca}^{2+}$ transients (Fig. $2 \mathrm{~B}$ ), suggesting that voltage-dependent $\mathrm{Na}^{+}$channels did not support bAP propagation into these more distal regions. These results suggest that bAP propagation in distal dendritic regions is decrementing in MSNs, much as in the distal dendrites of CA1 pyramidal neurons (Magee et al., 1998; Bernard and Johnston, 2003). 


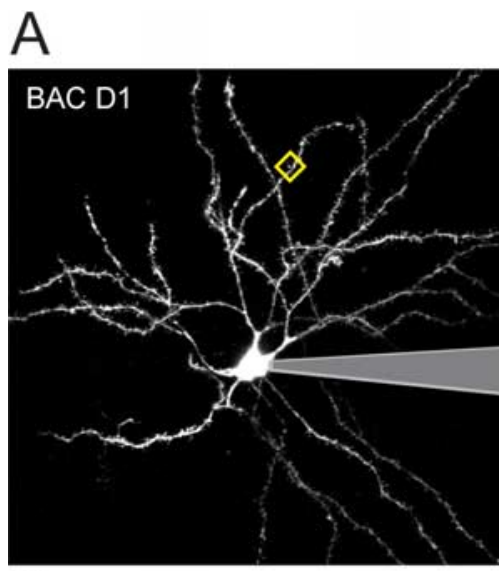

B
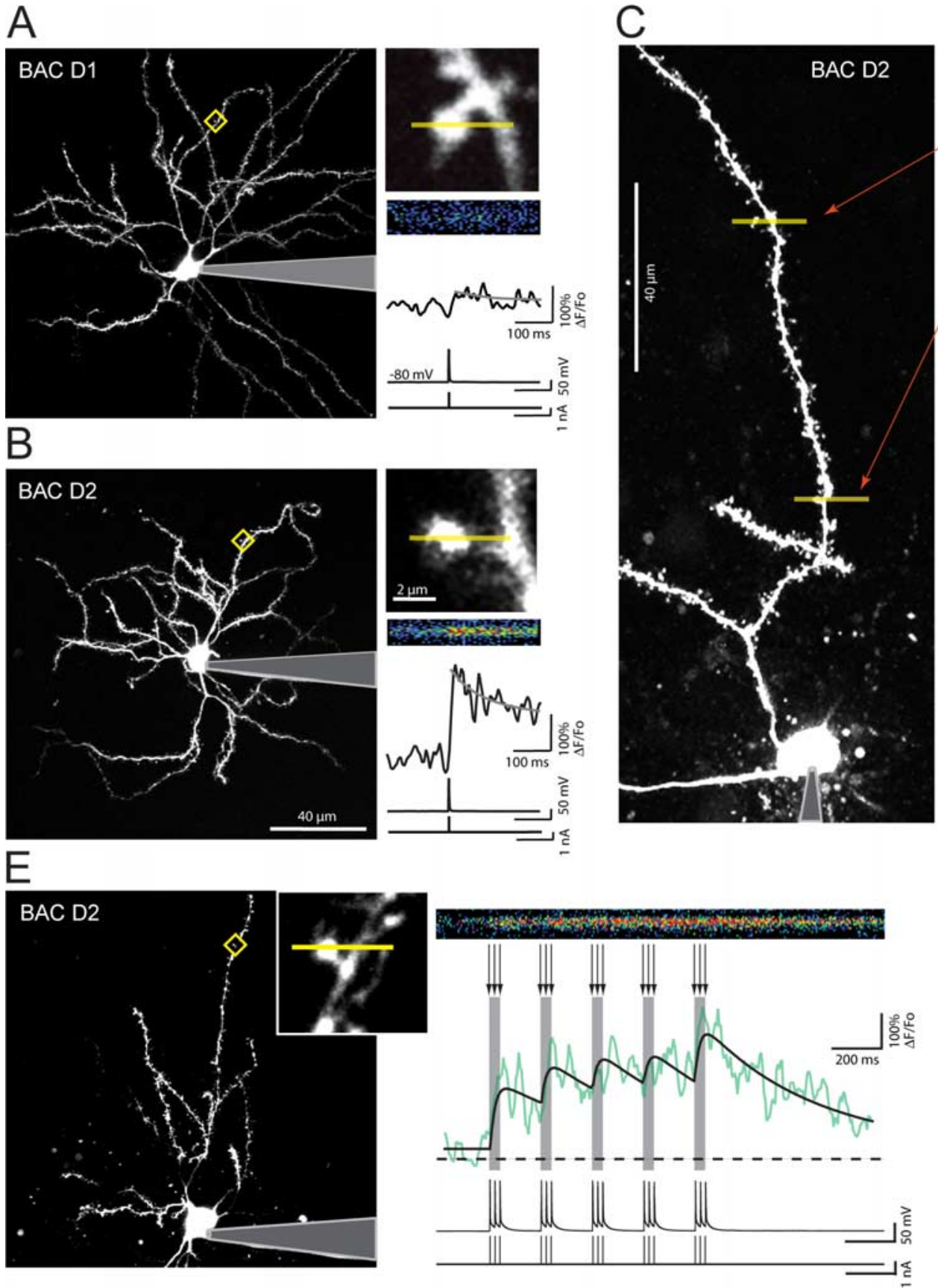

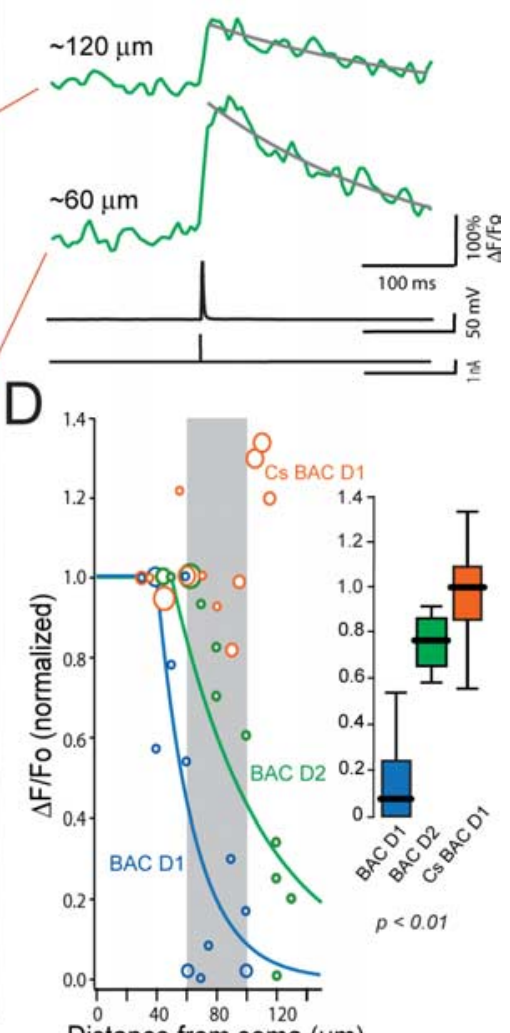

$\mathrm{F}$

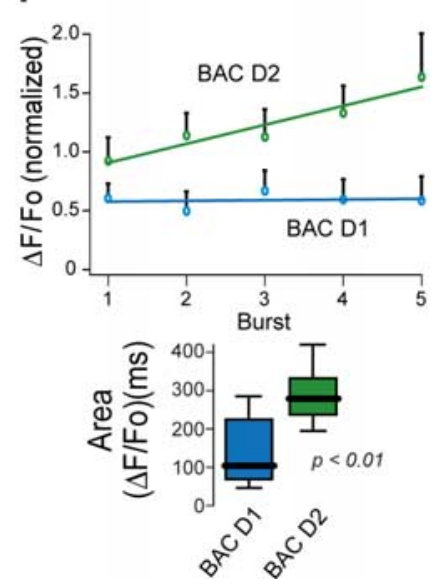

Figure 1. BAP-evoked $\mathrm{Ca}^{2+}$ transients are readily detected in the distal dendrites and spines of the $D_{2}$ population of MSNs. $A, B, 2 P L S M$ images of MSNs in $275-\mu \mathrm{m}$-thick corticostriatal slices from $\mathrm{a} B A C D_{1}(A)$ and $B A C D_{2}(B)$ mouse. Neurons were visualized with Alexa Fluor $568(50 \mu \mathrm{m})$ by filling through the patch pipette (patch pipettes are grayed-out for presentation). Maximum projection images of the somas and dendritic fields ( $\boldsymbol{A}$ and $\boldsymbol{B}$, left panels) and high-magnification projections of dendrite segments from the regions outlined by the yellow boxes are shown ( $\boldsymbol{A}$ and $\boldsymbol{B}$, top right panels). BAP-evoked $\mathrm{Ca}^{2+}$ transients were detected by line scanning through the spine in the region indicated by the yellow line. Fluorescence traces were generated from the pseudocolor image ( $\boldsymbol{A}$ and $\boldsymbol{B}$, lower panels) by calculating $\Delta F / F_{0}$ (top black trace). The fluorescence image, $\Delta F / F_{0}$ trace, action potential (middle trace) and current pulse (bottom trace) are shown in temporal registration. C, Maximum projection image of a soma and dendritic branch from a $D_{2}$ MSN. Line scans were acquired at 2 eccentricities, 120 and $60 \mu \mathrm{m}$, as indicated by the red arrows. $\boldsymbol{D}$, Graph of the change in amplitude with distance from the soma calculated by normalizing the distal bAP-evoked $\mathrm{Ca}^{2+}$ transient to the most proximal transient in each MSN. The magnitude of the $\mathrm{Ca}^{2+}$ transients decrements more in the $D_{1} M S N s$ ( $D_{1} M S N s$, open blue circles; $D_{2} M S N s$, open green circles). This decrementation is not seen in MSNs loaded with $C^{+}$based internals (open orange circles). The points were scaled to represent the number of cells scanned at each point (smallest points, 1 cell; largest points, 4 cells). The data, fit from the median distance of the most proximal point, shows that the magnitude of the $\mathrm{Ca}^{2+}$ transients decrements more in the $\mathrm{D}_{1} \operatorname{MSNs}\left(n=11\right.$, blue line) vs the $\mathrm{D}_{2} \operatorname{MSNs}(n=6$, green line) (Kruskal-Wallis ANOVA, $p<0.01)$. $\boldsymbol{E}$, Maximum projection image of the soma and dendritic field of a $D_{2}$ MSN. A high-magnification image of the dendritic segment outlined in the yellow box is shown in the inset. Scale bars in $B$ apply to both images. The pseudocolor image, $\Delta F / F_{0}$ trace, action potential (middle trace) and current pulse (bottom trace) are shown in temporal registration. Arrows indicate the timing of current pulses delivered to initiate APs. $F$, Average peak $\Delta F / F_{0}$ values after each of the five pulses constituting the theta burst bAP protocol. Values are from distal dendritic spines (100-120 $\mu \mathrm{m}$ from the soma), and normalized to the maximum peak $\Delta F / F_{0}$ value measured in a proximal spine $(60-80 \mu \mathrm{m})$ of the same dendrite in response to the first burst of the same theta burst protocol. The area under the $\Delta F / F_{0}$ plot was calculated for each cell type in response to the entire theta burst protocol; in line with larger peak $\mathrm{Ca}^{2+}$ transients, the box plots to the right demonstrate significantly larger $\mathrm{Ca}^{2+}$ transient areas in the $D_{2}$ vs the $D_{1}$ MSNs (Kruskal-Wallis ANOVA, $p<0.05$ ). 


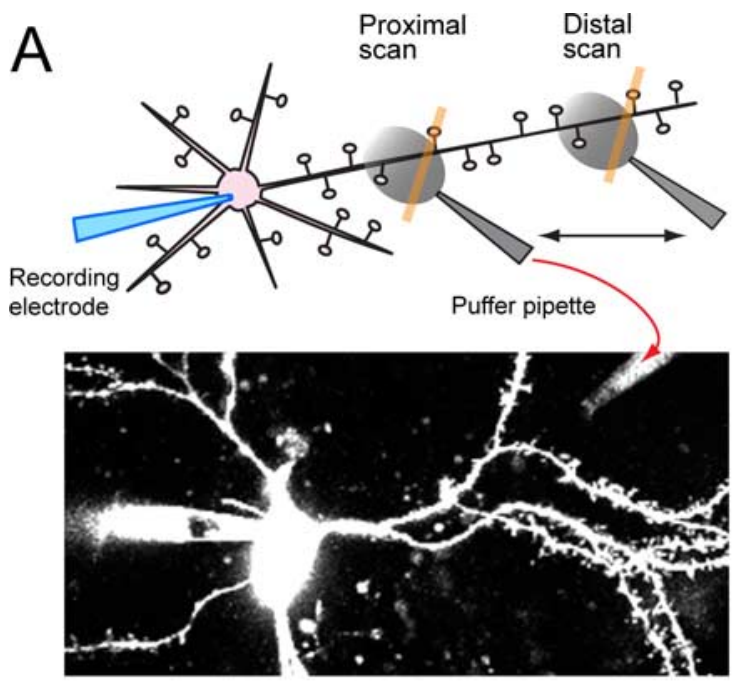

$\mathrm{B}$

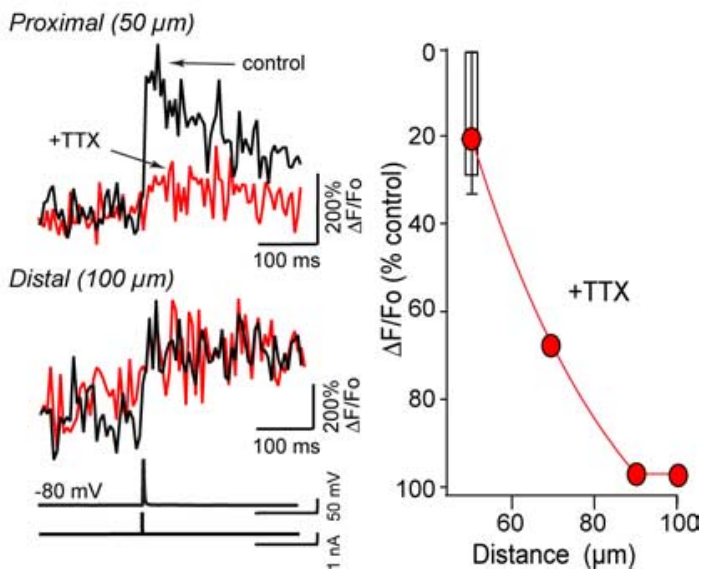

Figure 2. Action potentials actively propagate into $D_{2}$ MSN dendrites. $A$, Maximum projection image of a $D_{2}$ MSN showing both the scan site (yellow line) and the puffer pipette which contained Alexa Fluor $568(10 \mu \mathrm{M})$ for guiding placement and TTX (1 $\mu \mathrm{M})$ for blocking Nav channels. $B$, The $\Delta F / F_{0}$ traces (top), action potential (middle trace), and current pulse (bottom trace) are shown in temporal registration. The fluorescence traces show the bAP-evoked $\mathrm{Ca}^{2+}$ transient before (black) and during TTX ejection (red). The box plot shows the marked reduction in the amplitude of the proximal bAP-evoked $\mathrm{Ca}^{2+}$ transient with the median value being $20 \%$ of the control value ( $n=5$ cells).

\section{$\mathrm{Kv} 4 \mathrm{~K}^{+}$channels regulate dendritic excitability}

The somatic excitability of MSNs is regulated by an array of $\mathrm{K}^{+}$ channels, most prominently channels with Kir2, Kv1, Kv2, Kv4, and Kv7 pore-forming subunits. Of these, Kv1 and Kv4 channels are the most likely to play a significant role in regulating dendritic bAP invasion in MSNs (Johnston et al., 2000; Tkatch et al., 2000; Shen et al., 2004). MSNs express Kv1.1, Kv1.2, and Kv1.6 channels. To test their involvement in dendritic electrogenesis, the $\mathrm{Ca}^{2+}$ transient evoked by bAPs was compared before and after bath application of $\alpha$-dendrotoxin ( $\alpha$-DTX) (Harvey, 2001). Spines and adjacent shafts at distances from the soma where the bAP $\mathrm{Ca}^{2+}$ transient was beginning to decrement $(60-120 \mu \mathrm{m})$ were examined. There was no change in the bAP-evoked dendritic $\mathrm{Ca}^{2+}$ transient after $\alpha$-DTX (500 nM, red traces) in either $\mathrm{D}_{1}$ (Fig. $\left.3 A\right)$ or $\mathrm{D}_{2} \mathrm{MSNs}$ (Fig. $\left.3 B\right)(n=5$ each), despite the fact that the somatic response to intracellular current injection was unequivocally altered by the treatment (Fig. 3C,D). In agreement with the inference that Kv1 channels were not playing a major role in regulating bAPs, $100 \mu \mathrm{M}$ 4-aminopyridine (4-AP) also failed to alter bAP-evoked transients in dendritic shafts or spines ( $n=4$, data not shown).

To test for the involvement of other $\mathrm{K}^{+}$channels, the bAPassociated dendritic $\mathrm{Ca}^{2+}$ transient was examined before and after bath application of higher concentrations of 4-AP. MSNs robustly express Kv2 and Kv4 channels (Tkatch et al., 2000; Ariano et al., 2005). As mentioned above, low concentrations of 4-AP that do not effectively block Kv4 channels (100 $\mu \mathrm{M})$ were without effect. Elevating the 4-AP concentration to $500 \mu \mathrm{M}$, a concentration that should block a significant proportion of Kv2 (and Kv3) channels, also failed to significantly alter the bAPassociated $\mathrm{Ca}^{2+}$ transient (Fig. $4 A$ ) ( $n=4$, pink traces). However, increasing the 4 -AP concentration to $1 \mathrm{mM}$ (the $\mathrm{IC}_{50}$ for $\mathrm{Kv} 4$ channels is near $2 \mathrm{mM}$ ) clearly increased the dendritic $\mathrm{Ca}^{2+}$ transient. In all of the $\mathrm{D}_{2} \mathrm{MSN}$ tested $(n=5), 4-\mathrm{AP}(1 \mathrm{mM})$ increased the amplitude of the bAP-evoked $\mathrm{Ca}^{2+}$ transient in proximal ( $\sim 60 \mu \mathrm{m}$ from soma) dendritic shafts and spines (Fig. $4 A, B$ ) (black traces $=$ control, red traces $=4-\mathrm{AP})$. Likewise, bAPevoked $\mathrm{Ca}^{2+}$ transients were enhanced in the distal $(\sim 120 \mu \mathrm{m}$ from soma) dendritic shafts and spines of $D_{1}$ and $D_{2}$ MSNs (Fig. $4 A-C)$. In all of the $\mathrm{D}_{1}$ MSNs tested $(n=4), 4$-AP also enhanced the bAP-evoked $\mathrm{Ca}^{2+}$ transients in proximal dendritic shafts and spines, as seen in $\mathrm{D}_{2}$ MSNs (Fig. $4 \mathrm{~B}$ ). The percentage increase in the distal bAP-evoked transient by 4 -AP was not calculable in $\mathrm{D}_{1}$ MSNs because the control transient was normally not detectable. Increasing the extracellular 4-AP concentration to $2 \mathrm{~mm}$ had an even more dramatic effect on the dendritic $\mathrm{Ca}^{2+}$ transients (traces not shown). To better evaluate the impact of Kv4 channels on the differences in the attenuation of the bAP-associated $\mathrm{Ca}^{2+}$ signal in $\mathrm{D}_{1}$ and $\mathrm{D}_{2} \mathrm{MSNs}$, the ratio of the distal $(100-120 \mu \mathrm{m})$ to proximal $(40-60 \mu \mathrm{m})$ dendritic $\mathrm{Ca}^{2+}$ transients was measured (as described above, see Fig. $1 D$ ) in the presence of $1 \mathrm{~mm} 4-\mathrm{AP}$. For the purposes of comparison, control data from Figure $1 D$ is reproduced in Figure $4 C$ (lightly shaded boxes). In both $\mathrm{D}_{1}$ and $\mathrm{D}_{2}$ MSNs, 4-AP eliminated the attenuation in the spine $\mathrm{Ca}^{2+}$ transient; in distal dendritic shafts the $\mathrm{Ca}^{2+}$ transient was typically larger than that seen in the proximal dendrites in the presence of 4-AP (Fig. 4C). These results suggest that $\mathrm{Kv} 4 \mathrm{~K}^{+}$channels were a major factor in the attenuation of the bAP signal.

To determine whether Kv4.2 channel proteins were properly positioned to regulate bAPs in MSNs, an immunocytochemical approach was used. Primary cell cultures were generated from the striatum of BAC $\mathrm{D}_{2}$ GFP mice and the cortex of wild-type mice (Segal et al., 2003). In these cocultures, the dendrites and spines of MSNs strongly resemble those found in vivo. However, unlike the situation in vivo, the dendrites of MSNs are planar and isolated, increasing the ability to unequivocally localize proteins with immunocytochemical approaches. Probing nonpermeabilized three-week old cocultures with an antibody directed to an extracellular epitope of the Kv4.2 subunit revealed intense labeling of soma and dendrites (Fig. $4 \mathrm{D}$, red signal, left panel, top). $\mathrm{D}_{2}$ MSNs were identified by GFP fluorescence (Fig. 4D, middle panel). Overlaying the images revealed a clear expression of Kv4.2 channel protein in the shafts and spines of these MSNs (yellow, right panel, top). The labeling of distal dendritic shafts and spines was more readily seen in higher magnification images (Fig. 4D, bottom panels). Together, these results strongly suggest that $\mathrm{Kv} 4.2 \mathrm{~K}^{+}$channels are appropriately positioned to regulate dendritic excitability and bAP invasion in MSNs.

The obvious problem with the inference that $\mathrm{Kv} 4$ channels are important regulators of the dendritic depolarization associated with bAPs is the lack of 4-AP selectivity. Although the dose dependence of the 4-AP effect provides some measure of assurance 

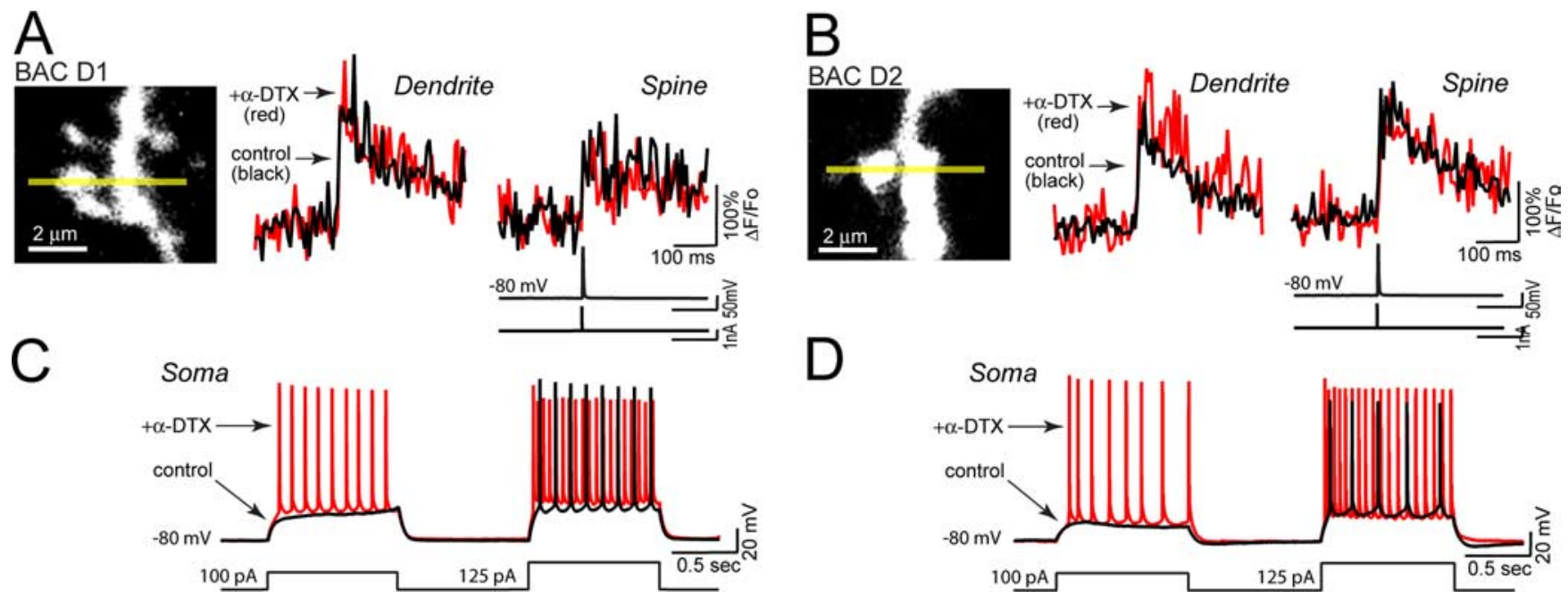

Figure 3. Kv1.2 channels regulate somatic, but not dendritic, excitability in MSNs. $\boldsymbol{A}, \boldsymbol{B}$, Line scans taken $45-60 \mu \mathrm{m}$ from the soma show that blockade of Kv1.2 channels with $\alpha$-DTX (0.5 $\mu \mathrm{m}$ ) does not effect the amplitude of the bAP-evoked $\mathrm{Ca}^{2+}$ transient in dendrites (left traces $\boldsymbol{A}$ and $\boldsymbol{B}$ ) or adjacent spines (right traces $\boldsymbol{A}$ and $\boldsymbol{B}$ ) of either $\mathrm{D}_{1}$ or $\mathrm{D}_{2}$ MSNs (control $=$ black, $\alpha$-DTX $=$ red, $n=5$ each). $\boldsymbol{C}, \boldsymbol{D}$, Somatic voltage recordings from the MSNs shown in $\boldsymbol{A}$ and $\boldsymbol{B}$ demonstrate that spiking is enhanced by $\alpha$-DTX in both $\mathrm{D}_{1}$ and $\mathrm{D}_{2}$ MSNs (control $=$ black, $\alpha$-DTX $=$ red). Recordings were generated by injecting sequential depolarizing current steps at amplitudes just before and after rheobase potentials (100 and $125 \mathrm{pA}$, lower black line).

that Kv4 channels and not Kv1 channels are involved, 4-AP is capable of blocking other $\mathrm{K}^{+}$channels. $\mathrm{Ba}^{2+}$ also blocks $\mathrm{Kv} 4$ channels (Coetzee et al., 1999), but also blocks Kir2 $\mathrm{K}^{+}$channels, which are prominent in MSNs. At present, there is no consensus on the specificity of organic toxins for Kv4 channels, undermining any pharmacological approach to the problem. As an alternative, we took a computational approach. A computational model of an MSN was created using NEURON that faithfully reproduced key features of the dendritic architecture and known intrinsic ionic mechanisms (Wilson et al., 1983) (supplemental Fig. S2, available at www.jneurosci.org as supplemental material). In our model, there was a steep $\mathrm{Na}^{+}$channel gradient from the axon initial segment and soma into the dendrites, with tertiary dendrites being devoid of these channels, consistent with the observations described above. The density of Kv4 channels was assumed to be uniform, the most parsimonious assumption given the anatomical data on hand. Simulation of dendritic bAP invasion with this model suggest that the absence of $\mathrm{Na}^{+}$channels in tertiary dendritic branches led to an attenuation of the dendritic depolarization produced by bAPs, with the peak of the depolarization near $-45 \mathrm{mV}$ in the middle portions of the tertiary branches (supplemental Fig. S2, available at www.jneurosci.org as supplemental material). This depolarization was sufficient to activate relatively low voltage-activated Cav1.3 $\mathrm{Ca}^{2+}$ channels placed in the dendrites (supplemental Fig. S2, available at www. jneurosci.org as supplemental material), as previous work has shown them to be localized in these MSN regions (Olson et al., 2005). More importantly, downregulation of Kv4 channels alone enhanced the bAP associated voltage change in distal dendrites and, in so doing, increased the opening of voltage-dependent $\mathrm{Ca}^{2+}$ channels (supplemental Fig. S2, available at www. jneurosci.org as supplemental material). The augmented $\mathrm{Ca}^{2+}$ channel opening led to a significant elevation in dendritic $\mathrm{Ca}^{2+}$ concentration, much like that seen experimentally after 4-AP application (supplemental Fig. S2, available at www.jneurosci.org as supplemental material). These simulations show that downregulation of $\mathrm{Kv} 4$ channel opening was sufficient to explain the elevation in dendritic $\mathrm{Ca}^{2+}$ concentration after 4-AP application, but a definitive resolution of this issue requires the development of better tools.

\section{DA and muscarinic receptors differentially modulate dendritic $\mathrm{Ca}^{2+}$ transients}

In the healthy striatum, DA and acetylcholine (ACh) (released from giant interneurons) are key modulators of synaptic integration and plasticity (Surmeier et al., 2007). Adaptations in MSN connectivity and dendritic architecture in PD models are dependent on the loss of DA and the consequent rise in ACh signaling through broadly expressed $\mathrm{M}_{1}$ muscarinic receptors (Day et al., 2006; Shen et al., 2007). How these changes in neuromodulator levels translate into changes in dendritic $\mathrm{Ca}^{2+}$ is incompletely understood. In MSN perisomatic membranes, $\mathrm{D}_{2}$ and $\mathrm{D}_{1}$ receptors have been found to couple to voltage-dependent $\mathrm{Ca}^{2+}$ channels (Surmeier et al., 1995; Hernández-López et al., 1997, 2000; Olson et al., 2005), but it is not clear that the same coupling is present in dendrites. To move toward a better grasp of these mechanisms, the ability of DA to modulate bAP-evoked $\mathrm{Ca}^{2+}$ transients was tested. In the presence of ionotropic and metabotropic glutamate and GABA receptor antagonists, local puffer application of DA $(100 \mu \mathrm{M})$ to the dendrites of $\mathrm{D}_{2}$ MSNs reduced the bAP-associated $\mathrm{Ca}^{2+}$ transient $(n=3)$ (Fig. $5 A$, top traces). This effect was mimicked by the $\mathrm{D}_{2}$ receptor agonist quinpirole $(10 \mu \mathrm{M}, n=5)$ (Fig. $5 A$, bottom traces, $5 B$ ). In contrast, DA application had no detectable effect on bAP-associated $\mathrm{Ca}^{2+}$ transients in $\mathrm{D}_{1}$ MSNs $(n=5)$ (Fig. $\left.5 B\right)$. This result argues that the negative coupling of $\mathrm{D}_{2}$ receptors to $\mathrm{Ca}^{2+}$ channels in perisomatic membrane (Hernández-López et al., 2000) extends into the dendritic shafts and spines of $\mathrm{D}_{2}$ MSNs.

In the perisomatic membrane of MSNs, muscarinic receptors also negatively couple to $\mathrm{Ca}^{2+}$ channels. There, $\mathrm{M}_{1}$ muscarinic receptor signaling in both $\mathrm{D}_{2}$ and $\mathrm{D}_{1}$ MSNs diminishes the opening of Cav1 channels, whereas $\mathrm{M}_{4}$ receptor signaling decreases the opening of Cav2 channels preferentially in $\mathrm{D}_{1}$ MSNs (Howe and Surmeier, 1995; Yan et al., 2001). In the same mixture of glutamate and GABA receptor antagonists, focal application of muscarine $(20 \mu \mathrm{M})$ to the dendrites of $\mathrm{D}_{2}$ MSNs $(60-100 \mu \mathrm{m}$ from 
A
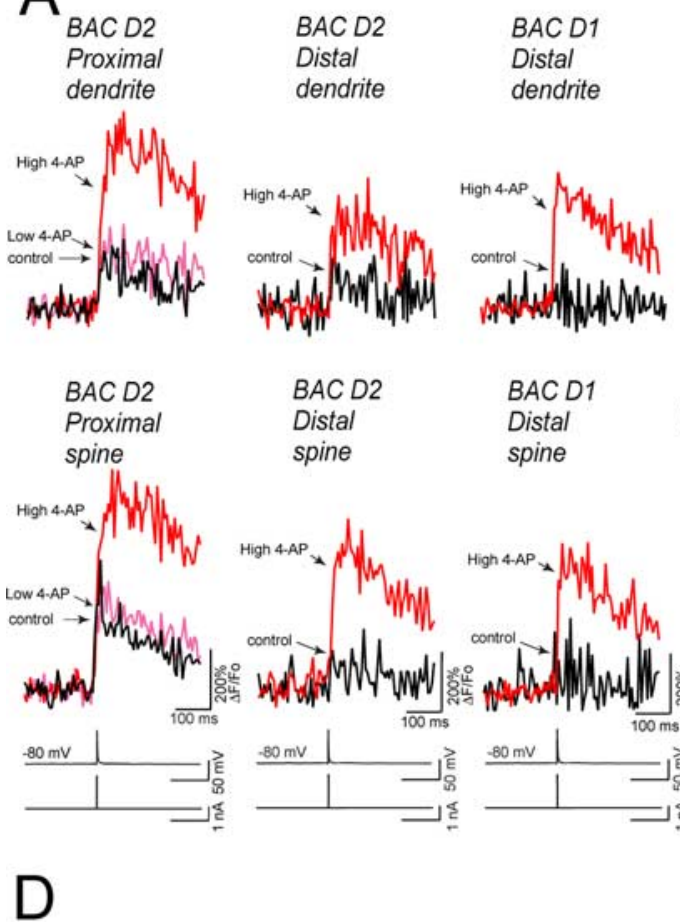

\section{eGFP}
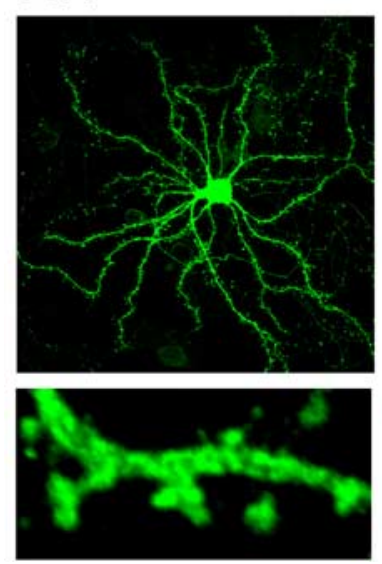

Anti-Kv4.2
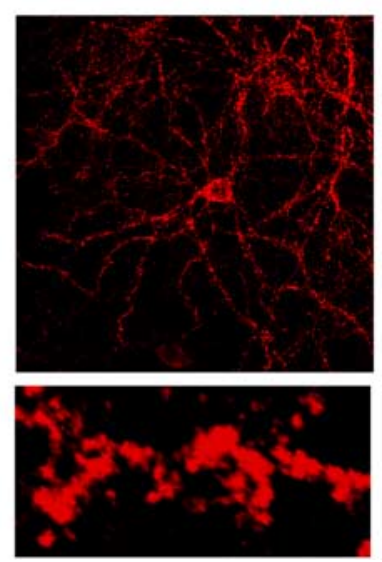

B
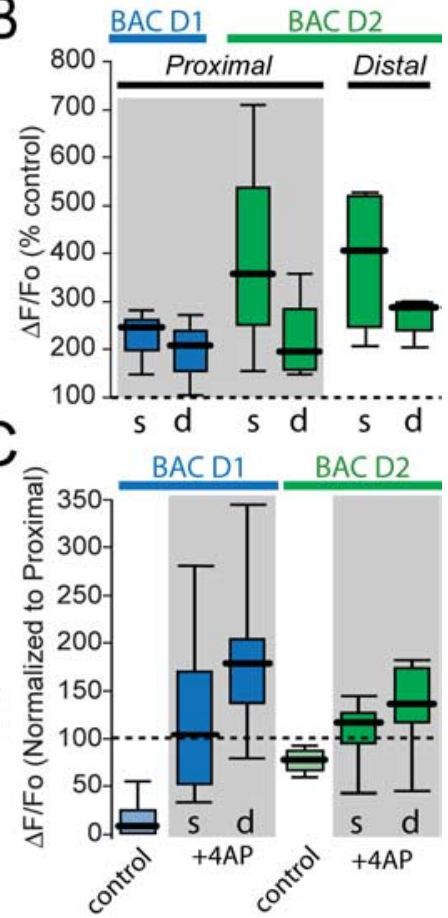

Overlay
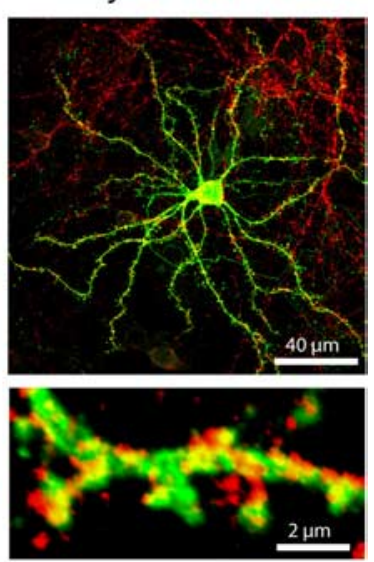

Figure 4. Kv4.2 channels regulate excitability of dendrites and spines in $D_{1}$ and $D_{2} M S N s . A$, Line scans taken at $\sim 60 \mu \mathrm{m}$ from the soma show that blockade of Kv4.2 channels with $1 \mathrm{~mm}$ 4-AP enhanced the amplitude of the bAP-evoked $\mathrm{Ca}^{2+}$ transient in proximal dendrites (top left traces) and adjacent spines (bottom left traces) in $\mathrm{D}_{2}$ MSNs. Blockade of Kv1.2 channels with $0.5 \mathrm{~mm}$ 4-AP in the same proximal spine/dendrite pairs had no effect on bAP-evoked $\mathrm{Ca}^{2+}$ transient (pink traces). Similarly, line scans taken at $\sim 120 \mu \mathrm{m}$ from the soma show that blockade of Kv4.2 channels with $1 \mathrm{~mm}$ 4-AP enhanced the amplitude of the bAP-evoked $\mathrm{Ca}^{2+}$ transient in distal dendrites (top right traces) and adjacent spines (bottom right traces) in $\mathrm{D}_{2}$ and $\mathrm{D}_{1} \mathrm{MSN}$ (control, black; $1 \mathrm{~mm}$ 4-AP, red). B, Box plot shows the increase in the amplitude of the bAP-evoked $\mathrm{Ca}^{2+}$ transient in $1 \mathrm{~mm}$ 4-AP with the median percentage of control in proximal $D_{1}$ spines, 248\%; dendrites, 208\% ( $n=4$ cells, $D_{1}$ fluorescence traces not shown). The median percentage of control in proximal $D_{2}$ spines $=359 \%$, dendrites $=195 \%$; distal $D_{2}$ spines $=406 \%$ and $D_{2}$ dendrites $=289 \%(n=5$ cells $)$. C, Box plot shows the amplitude of the bAP-evoked $\mathrm{Ca}^{2+}$ transient of distal dendrites and spines normalized to the proximal $\mathrm{Ca}^{2+}$ transient in each cell, in the presence of $1 \mathrm{~mm}$ 4-AP. The median normalized distal $\mathrm{Ca}^{2+}$ transient in $D_{1}$ spines $=103.2 \%$ and $D_{1}$ dendrites $=178.2 \%(n=5$ cells $) ; D_{2}$ spines, $116.2 \%$ and $D_{2}$ dendrites, $135.8 \%(n=4$ cells). As a reference light blue and light green boxes represent the data for $D_{1}$ and $D_{2}$ cells, respectively, in the absence of 4-AP, taken from Figure 1.D, Anti-Kv4.2 labeling in cultured neurons from a $B A C D_{2}$ mouse (red fluorescence, center panel, top). EGFP fluorescence (left panel, top). Overlay of the red and green images revealed a clear expression of Kv4.2 channel protein in $D_{2} G F P+$ neurons (yellow, right panel, top). High-magnification images of the dendritic processes show Kv4.2-channel protein labeling in dendrites and spines (Fig. 4D, bottom panels).

the soma) significantly increased (not decreased) the bAPassociated $\mathrm{Ca}^{2+}$ transient $(n=5)$ (Fig. $\left.5 C, D\right)$. In contrast, puffing muscarine on the proximal portion of the $\mathrm{D}_{1}$ MSNs dendritic tree (45-60 $\mu \mathrm{m}$ from the soma) had no effect on bAP associated
$\mathrm{Ca}^{2+}$ transients in spines $(n=5)$ (Fig. $5 D)$. In pyramidal neurons, $\mathrm{M}_{1}$ muscarinic receptor signaling potently downregulates $\mathrm{Kv} 4 \mathrm{~K}^{+}$channel opening in response to membrane depolarization and increases bAP amplitude in distal dendritic regions (Hoffman and Johnston, 1998; Yuan et al., 2002). If $M_{1}$ muscarinic receptor signaling was doing something similar in MSNs to enhance $\mathrm{Ca}^{2+}$ channel opening, then blocking Kv4 channels should occlude the effects of $M_{1}$ receptor stimulation. To test this hypothesis, 4-AP (1 mM) was bath applied and then muscarine was puffed on the dendrites of $\mathrm{D}_{2} \mathrm{MSN}$. As predicted, in this situation muscarine had little or no effect on the bAP-evoked change in dendritic fluorescence $(n=5)$ (Fig. $5 C, D)$, suggesting that $\mathrm{Kv} 4$ channels are dendritic targets of muscarinic receptor signaling.

\section{DA depletion enhances bAP invasion in $\mathrm{D}_{2}$ MSNs}

The experiments described thus far show that DA-receptor signaling diminishes bAP-evoked $\mathrm{Ca}^{2+}$ transients, whereas ACh-receptor signaling increases bAPevoked $\mathrm{Ca}^{2+}$ transients in $\mathrm{D}_{2} \mathrm{MSN}$ s. In PD models, striatal DA levels fall and ACh signaling rise, suggesting that there should be a profound increase in dendritic excitability in $\mathrm{D}_{2}$ MSNs, at least acutely. What happens with sustained DA depletion is less clear. To pursue this question, $\mathrm{BAC} \mathrm{D}_{2}$ mice were DA depleted for $5 \mathrm{~d}$ using reserpine (LaHoste et al., 1993; Kachroo et al., 2005). Previous work by our group has shown that this produces a profound loss of spines in $\mathrm{D}_{2}$ MSNs that is mimicked by 6-hydroxydopamine lesions of the nigrostriatal dopaminergic system (Day et al., 2006). This spine pruning requires the opening of depolarization-activated Cav1.3 $\mathrm{Ca}^{2+}$ channels and is attenuated by genetically deleting $M_{1}$ muscarinic receptors (Day et al., 2006; Shen et al., 2007). In brain slices from DA-depleted mice, the bAP-evoked $\mathrm{Ca}^{2+}$ transient was mapped in the dendrites of $\mathrm{D}_{2}$ MSNs. As described above, the amplitude of the fluorescence change $\left(\Delta F / F_{0}\right)$ at distal dendritic sites was normalized by the proximal fluorescence signal. In $\mathrm{D}_{2}$ MSNs from DA-depleted mice, the relative amplitude of bAP-evoked $\mathrm{Ca}^{2+}$ transient in dendritic shafts and spines fell less steeply with distance from the soma than in untreated neurons $(n=4)$

(Fig. 6A). At distal dendritic locations (100 and $150 \mu \mathrm{m}$ from the soma), DA depletion significantly increased the relative amplitude of the $\mathrm{Ca}^{2+}$ transient evoked by a single bAP (Fig. $6 B)(n=4$ each). In fact, in all of the neurons examined after DA depletion, bAP-associated $\mathrm{Ca}^{2+}$ 
transients were detectable as far out on the dendrites as we were capable of imaging ( $\sim 150 \mu \mathrm{m}$ from the soma).

Based on the work described above in the normosensitive striatum, the simplest explanation of this change is that it reflects the loss of $\mathrm{D}_{2}$ receptor and the gain of M1 receptor activity after reserpine treatment. As a first step toward testing this hypothesis, the amplitudes of bAP-evoked $\mathrm{Ca}^{2+}$ transients in untreated $\mathrm{BAC} \mathrm{D}_{2}$ MSNs were recorded before and after bath application of the $\mathrm{D}_{2}$ antagonist sulpiride $(10 \mu \mathrm{M})$ to determine whether ambient DA release in the brain slice contributed to the profile of dendritic excitability measured. There was not any significant change in the bAP-evoked $\mathrm{Ca}^{2+}$ transient in distal dendrites after $\mathrm{D}_{2}$ blockade, indicating that ambient DA release was not a factor $(n=5$, data not shown). To test for the possibility that DA depletion elevated M1 muscarinic receptor activity, the muscarinic antagonist scopolamine $(20 \mu \mathrm{M})$ was bath applied to slices from reserpinized mice; scopolamine significantly reduced the bAP-evoked $\mathrm{Ca}^{2+}$ transient in $\mathrm{D}_{2}$ MSNs $(n=5)$ (Fig. 6C).

Another potential factor in the enhanced dendritic excitability of $\mathrm{D}_{2}$ MSNs after DA depletion is the loss of spines and dendritic surface area itself. This loss should diminish the capacitative load of the dendrites and improve bAP invasion into distal regions. Although consistent with theoretical and experimental examination of other neurons (Wilson, 1992), this hypothesis was tested in an anatomically representative model of an MSN. NEURON simulations were conducted in which the surface area of spiny dendrites was decreased and the effects on the bAP examined. These simulations corroborated the inference that spine loss enhances dendritic bAP invasion, showing enhanced bAP propagation, enhanced opening of voltage-dependent $\mathrm{Ca}^{2+}$ channels and an elevation in bAP-evoked change in intracellular $\mathrm{Ca}^{2+}$ concentration at distal dendritic locations (supplemental Fig. S3, available at www. jneurosci.org as supplemental material).

\section{Discussion}

Striatal MSNs are the principal neurons of the striatal circuitry that controls a wide array of psychomotor behaviors. Yet, relatively little is known about how intrinsic dendritic mechanisms govern the integration of synaptic signals. A major obstacle to gaining a better understanding of these regions is their small size and largely nonplanar organization. Optical approaches, particularly 2PLSM, offer a powerful strategy for probing dendritic function, particularly when used in conjunction with somatic patch-clamp recordings. This approach has recently been used to study proximal MSN dendrites (Carter and Sabatini, 2004; Carter et al., 2007). Our results extend these observations to more distal dendritic regions of MSNs and to differences between the two major subtypes of striatal MSNs. Our studies support four basic conclusions. First, bAPs are actively propagated in the proximal dendritic trees of MSNs, but appear to be passively propagated into more distal dendritic regions; moreover, this propagation is more robust in $\mathrm{D}_{2}$ MSNs than in $\mathrm{D}_{1}$ MSNs. Second, the propagation of potential changes produced by bAPs are actively shaped by dendritic $\mathrm{K}^{+}$channels, most likely Kv4 channels, as has been described in CA1 pyramidal neurons (Bernard and Johnston, 2003). Third, the dendritic $\mathrm{Ca}^{2+}$ signal associated with a single bAP is modulated by focal application of both DA and $\mathrm{ACh}$ receptor agonists in $\mathrm{D}_{2}$ MSNs, but this bAP- 

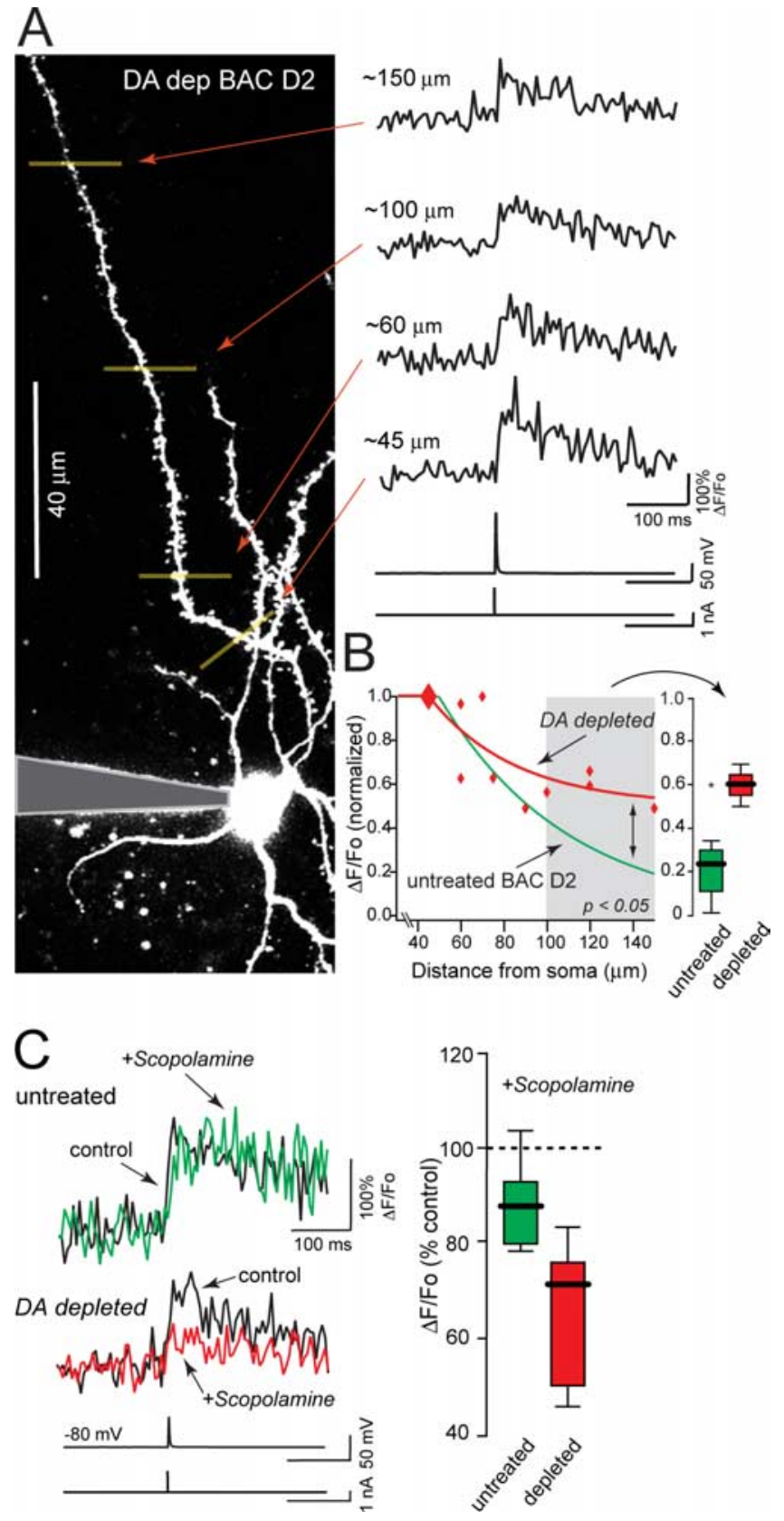

Figure 6. DA depletion enhances excitability in distal dendrites in $D_{2}$ MSNs. $A$, Maximum projection image of a $D_{2} M S N$ soma and dendrite from a DA-depleted $B A C D_{2}$ mouse (left). The traces show the bAP-evoked $\mathrm{Ca}^{2+}$ transient recorded at four different eccentricities along this dendrite $\left(45,60,100,150 \mu \mathrm{m}\right.$, right). $\boldsymbol{B}$, Plot of the amplitude of the bAP-evoked $\mathrm{Ca}^{2+}$ transient normalized to the most proximal recording in each cell (red diamonds, line). For comparison, the fit line from the $D_{2}$ untreated MSNs (Fig. 1D, green line) is added to the plot. The box plot demonstrates the increase in the amplitude of the normalized bAP-evoked $\mathrm{Ca}^{2+}$ in the distal regions of the DA-depleted $D_{2}$ MSN dendrites compared with control (untreated $D_{2}=$ $0.24, n=4$; DA-depleted $D_{2}=0.6, n=4$; Kruskal-Wallis ANOVA, $p<0.05$ ). $C$, The top traces show the bAP-evoked $\mathrm{Ca}^{2+}$ transient in a distal dendrite from an untreated $B A C D_{2}$ mouse before (black) and during bath application of $20 \mu \mathrm{m}$ scopolamine (green). The bottom traces were taken from a distal dendrite in a DA-depleted $\mathrm{BACD}_{2}$ mouse before (black) and during bath application of $20 \mu \mathrm{m}$ scopolamine (red). The box plot shows that scopolamine suppresses bAPevoked $\mathrm{Ca}^{2+}$ transients in the DA-depleted mice compared with untreated controls with the median percentage modulation decreasing from $87 \%$ in untreated mice to $71 \%$ in the DA depleted mice ( $n=5$ cells each; Kruskal-Wallis ANOVA, $p<0.05$ ). associated signal is not reliably modulated in $\mathrm{D}_{1}$ MSNs. Last, DA depletion increases the dendritic $\mathrm{Ca}^{2+}$ signal associated with bAPs in $\mathrm{D}_{2}$ MSNs, adding an important new insight into the mechanisms underlying striatal adaptations in PD.

\section{Dendrites of $D_{2}$ MSNs are more excitable than those of $\mathrm{D}_{1}$ MSNs}

Individual action potentials generated at the soma produced reliable $\mathrm{Ca}^{2+}$ transients in proximal $(\sim 30-50 \mu \mathrm{m}$ from the soma) dendritic shafts and spines of both $\mathrm{D}_{2}$ and $\mathrm{D}_{1}$ MSNs. These bAPevoked $\mathrm{Ca}^{2+}$ transients were also reliably detected in more distal ( $\sim 100 \mu \mathrm{m}$ from to soma) dendrites and spines of the $\mathrm{D}_{2}$ MSNs. The relative amplitude of this fluorescence signal fell with distance beyond $\sim 50 \mu \mathrm{m}$ from the soma, presumably because the amplitude of the bAP-associated potential change also fell with eccentricity from the soma (Stuart and Sakmann, 1994; Spruston et al., 1995). The rate at which this signal fell with distance was significantly greater in $\mathrm{D}_{1}$ MSNs than in $\mathrm{D}_{2}$ MSNs. The attenuation of the dendritic $\mathrm{Ca}^{2+}$ transient with distance from the soma was not attributable to a parallel fall-off in the density of $\mathrm{Ca}^{2+}$ channels, as improving distal voltage control by filling cells with $\mathrm{Cs}^{+}$eliminated any obvious attenuation of the dendritic $\mathrm{Ca}^{2+}$ signal with distance from the soma. Rather, the attenuation was more likely to be caused by decrementing propagation of the bAP-evoked potential into distal dendrites. This inference is drawn from the observation that application of the $\mathrm{Na}^{+}$channel toxin TTX to the proximal dendrites virtually eliminated more distal bAP-evoked elevations in $\mathrm{Ca}^{2+}$ dependent fluorescence (indicating active propagation of the bAP through the proximal dendrites), whereas application of TTX to distal tertiary dendritic locations ( $\sim 60 \mu \mathrm{m}$ from the soma) had virtually no effect on bAP-evoked fluorescence changes. Computer simulations using a model that captured key features of the MSN geometry and channel expression, confirmed that in tertiary dendrites lacking $\mathrm{Na}^{+}$channels, bAPs declined in amplitude as they traveled away from the soma. But these simulations also suggested that, at least within the initial portion of the tertiary dendrites, the amplitude of the bAP was still sufficient to activate relatively low-threshold Cav1.3 or Cav3 $\mathrm{Ca}^{2+}$ channels (Carter and Sabatini, 2004).

Why there appears to be a greater attenuation of bAP propagation into the dendrites of $\mathrm{D}_{1}$ MSNs is entirely unclear. Studies in other neurons have shown that dendritic geometry is an important factor governing bAP propagation (Vetter et al., 2001; Schaefer et al., 2003). However, a recent study by our group (Gertler et al., 2008) failed to find any significant differences in the branching structure of $\mathrm{D}_{1}$ and $\mathrm{D}_{2} \mathrm{MSN}$ dendrites, although $\mathrm{D}_{1}$ MSNs had more primary dendrites. In agreement with this anatomical similarity, the electrotonic length of $D_{1}$ and $D_{2}$ MSN dendrites were indistinguishable. Another factor governing bAP propagation is the dendritic distribution of ion channels. Voltage-dependent $\mathrm{Na}^{+}$channels support bAPs, helping to maintain the amplitude of bAPs as they invade dendrites (Stuart and Sakmann, 1994). Voltage-dependent $\mathrm{K}^{+}$channels, on the other hand, oppose bAP propagation (Hoffman et al., 1997). Kir2 $\mathrm{K}^{+}$channels are robustly expressed in MSN dendrites (Prüss et al., 2005; Shen et al., 2007); however, inwardly rectifying Kir2 channels rapidly block at potentials above the $\mathrm{K}^{+}$equilibrium potential, making them poor regulators of bAP propagation. In other neurons, depolarization-activated Kv4 channels have been shown to be potent bAP regulators (Hoffman et al., 1997). Our work revealed that the dendrites of MSNs also are invested with Kv4 channels, in agreement with previous scRT-PCR studies showing Kv4.1-3 mRNA expression in MSNs (Tkatch et al., 
2000). Moreover, block of Kv4, but not Kv1, channels enhanced bAP-evoked dendritic $\mathrm{Ca}^{2+}$ signals. Simulations of bAP propagation suggested that reducing $\mathrm{Kv} 4$ density by half could readily account for the change in dendritic bAP-evoked $\mathrm{Ca}^{2+}$ signals. More importantly, partially blocking $\mathrm{Kv} 4 \mathrm{~K}^{+}$channels with 4-AP eliminated the attenuation in the $\mathrm{Ca}^{2+}$ transient in distal dendritic regions in both $\mathrm{D}_{1}$ and $\mathrm{D}_{2}$ MSNs. However, it is not clear that the differences in the dendritic excitability of $D_{1}$ and $D_{2}$ MSNs is directly dependent on $\mathrm{Kv} 4$ channel density or function. Alternative approaches (Kim et al., 2007) will be necessary to unequivocally answer this question.

\section{DA suppresses, whereas ACh enhances, dendritic excitability in the $\mathrm{D}_{2}$, but not $\mathrm{D}_{1}$, MSNs}

Asymmetries in the neuromodulatory effects of DA on striatopallidal and striatonigral MSNs have long been inferred from their differential expression of $D_{1}$ and $D_{2}$ receptors. $D_{1}$ receptor stimulation generally enhances the response to excitatory inputs, whereas $\mathrm{D}_{2}$ receptor stimulation attenuates responses to excitatory stimulation (Levine et al., 1996; Cepeda et al., 1998). Our results point to another example, showing that local application of DA diminishes bAP-evoked $\mathrm{Ca}^{2+}$ signals in the dendrites of striatopallidal $\mathrm{D}_{2}$ MSNs, but has no detectable effect on the same response in striatonigral $D_{1}$ MSNs. The $D_{2}$ receptor-mediated response in $\mathrm{D}_{2}$ MSNs is consistent with their negative coupling to the Cav1 $\mathrm{Ca}^{2+}$ channels likely to underlie the bAP-evoked response (Hernández-López et al., 2000; Carter and Sabatini, 2004; Olson et al., 2005). Although ambient $\mathrm{D}_{2}$ receptor stimulation was not a factor underlying the asymmetry between MSNs $\left(\mathrm{D}_{2}\right.$ receptor antagonism had no effect on basal excitability in the slice), in vivo ongoing $\mathrm{D}_{2}$ receptor activity should reduce the differences in dendritic $\mathrm{Ca}^{2+}$ signaling between MSNs.

The absence of a dendritic response to DA application in $D_{1}$ MSNs is somewhat surprising. $D_{1}$ receptor protein is clearly present in the dendrites of MSNs (Hersch et al., 1995). Moreover, $\mathrm{D}_{1}$ receptor stimulation modulates ion channels that regulate dendritic $\mathrm{Ca}^{2+}$ transients. $\mathrm{D}_{1}$ receptor stimulation promotes the slow inactivation of $\mathrm{Na}^{+}$channels in MSNs (Calabresi et al., 1987; Carr et al., 2003); however, because slow inactivation only occurs at depolarized potentials, our experimental paradigm was not suited to bringing out this modulation. $\mathrm{D}_{1}$ receptor signaling also downregulates Cav2 and upregulates Cav1 $\mathrm{Ca}^{2+}$ channel opening in acutely isolated MSNs (Surmeier et al., 1995; Olson et al., 2005). Previous work also has shown that the $D_{1}$ receptormediated enhancement of NMDA responses is dependent on Cav1 channels (Cepeda et al., 1998). The failure to detect a clear effect of $\mathrm{D}_{1}$ agonists on bAP-evoked $\mathrm{Ca}^{2+}$ transients could be attributable to several experimental factors (e.g., disruption of intracellular signaling because of dialysis), but the most likely explanation is that this modulation is not effectively assayed by a single bAP.

In contrast to DA, it has generally been thought that $\mathrm{ACh}$ affects both classes of MSN similarly. All MSNs robustly express $\mathrm{M}_{1}$ muscarinic receptors (Yan et al., 2001). The other muscarinic receptor expressed by MSNs, the $\mathrm{M}_{4}$ receptor, is present in both classes, albeit at significantly higher levels in striatonigral $D_{1}$ MSNs (Bernard et al., 1992; Yan et al., 2001). Electrophysiological studies of muscarinic effects in randomly sampled MSNs have not found a pronounced heterogeneity in responses (Akins et al., 1990; Hersch et al., 1994; Galarraga et al., 1999). However, more recent work with BAC transgenic mice has found a much stronger $\mathrm{M}_{1}$ receptor-mediated modulation of dendritic Kir2 channels in $\mathrm{D}_{2}$ MSNs than in the $\mathrm{D}_{1}$ MSNs, a difference attributable to the susceptibility of targeted channels, not upstream signaling (Shen et al., 2007). Here, bAP-evoked dendritic $\mathrm{Ca}^{2+}$ transients were enhanced in $\mathrm{D}_{2}$ MSNs by local application of a muscarinic agonist, but not in $\mathrm{D}_{1} \mathrm{MSN}$. This modulation was occluded by 4-AP, suggesting that the modulation was mediated by $M_{1}$ receptor coupling to Kv4 channels, as found in pyramidal neurons (Hoffman and Johnston, 1998; Yuan et al., 2002). Why striatonigral $D_{1}$ MSNs should be unresponsive despite their expression of functional $\mathrm{M}_{1}$ receptors and the dendritic localization of $\mathrm{Kv} 4$ channels is not clear.

\section{Dendritic excitability of striatopallidal MSNs is enhanced in PD models}

In mouse models of $\mathrm{PD}, \mathrm{D}_{2}$ receptor-expressing striatopallidal MSNs, but not $\mathrm{D}_{1}$ receptor-expressing striatonigral MSNs, undergo a dramatic pruning of dendritic spines and synapses (Day et al., 2006). The reduction in spines requires activation of L-type Cav1.3 $\mathrm{Ca}^{2+}$ channels that are dendritically positioned through a scaffolding interaction with Shank (Zhang et al., 2005). How DA depletion increases the opening of dendritic Cav1.3 channels is uncertain. In acutely isolated $\mathrm{MSNs}, \mathrm{D}_{2}$ receptor signaling decreases the open probability of Cav1.3 channels (HernándezLópez et al., 2000; Olson et al., 2005). DA depletion would remove this inhibitory modulation if it existed in dendrites. Our results are consistent with this possibility, showing that dendritic $\mathrm{D}_{2}$ receptors decrease bAP-evoked $\mathrm{Ca}^{2+}$ transients.

Two additional factors are likely to contribute to increased Cav1.3 channel opening after DA depletion. First, DA depletion elevates cholinergic signaling in the striatum (Kopin, 1993). This should downregulate dendritic Kir2 and $\mathrm{Kv} 4 \mathrm{~K}^{+}$channels in $\mathrm{D}_{2}$ MSNs, increasing the dendritic depolarization produced by glutamatergic synapses and increasing bAP invasion into distal dendrites. The impact of elevated cholinergic signaling on bAPevoked $\mathrm{Ca}^{2+}$ transients after DA depletion was evident in our experiments. The importance of these $M_{1}$ receptor-mediated effects is underscored by attenuation of dendritic remodeling in $M_{1}$ receptor knock-out mice after DA depletion (Shen et al., 2007). In vivo, where $\mathrm{M}_{1}$ receptor tone is undoubtedly higher than in the slice, $\mathrm{D}_{2}$ MSN dendrites could be even more excitable after DA depletion. Second, the loss of spines and dendritic surface area should in and of itself elevate dendritic excitability by decreasing capacitive loading. Our simulations were consistent with this inference. This creates a potentially pathological positive feedback that could induce a progressive loss of spines and synapses in PD. This combination of mechanisms provides a framework within which the synaptic pruning seen in $\mathrm{D}_{2}$ MSNs of PD models can be understood and establishes potential therapeutic targets for PD patients.

\section{References}

Akins PT, Surmeier DJ, Kitai ST (1990) M1 muscarinic acetylcholine receptor in cultured rat neostriatum regulates phosphoinositide hydrolysis. J Neurochem 54:266-273.

Albin RL, Young AB, Penney JB (1989) The functional anatomy of basal ganglia disorders. Trends Neurosci 12:366-375.

Ariano MA, Cepeda C, Calvert CR, Flores-Hernández J, HernándezEcheagaray E, Klapstein GJ, Chandler SH, Aronin N, DiFiglia M, Levine MS (2005) Striatal potassium channel dysfunction in Huntington's disease transgenic mice. J Neurophysiol 93:2565-2574.

Baranauskas G, Tkatch T, Surmeier DJ (1999) Delayed rectifier currents in rat globus pallidus neurons are attributable to Kv2.1 and Kv3.1/3.2 $\mathrm{K}^{+}$ channels. J Neurosci 19:6394-6404.

Baranauskas G, Tkatch T, Nagata K, Yeh JZ, Surmeier DJ (2003) Kv3.4 subunits enhance the repolarizing efficiency of Kv3.1 channels in fast-spiking neurons. Nat Neurosci 6:258-266. 
Bernard C, Johnston D (2003) Distance-dependent modifiable threshold for action potential back-propagation in hippocampal dendrites. J Neurophysiol 90:1807-1816.

Bernard V, Normand E, Bloch B (1992) Phenotypical characterization of the rat striatal neurons expressing muscarinic receptor genes. J Neurosci 12:3591-3600.

Calabresi P, Mercuri N, Stanzione P, Stefani A, Bernardi G (1987) Intracellular studies on the dopamine-induced firing inhibition of neostriatal neurons in vitro: evidence for D1 receptor involvement. Neuroscience 20:757-771.

Carr DB, Day M, Cantrell AR, Held J, Scheuer T, Catterall WA, Surmeier DJ (2003) Transmitter modulation of slow, activity-dependent alterations in sodium channel availability endows neurons with a novel form of cellular plasticity. Neuron 39:793-806.

Carter AG, Sabatini BL (2004) State-dependent calcium signaling in dendritic spines of striatal medium spiny neurons. Neuron 44:483-493.

Carter AG, Soler-Llavina GJ, Sabatini BL (2007) Timing and location of synaptic inputs determine modes of subthreshold integration in striatal medium spiny neurons. J Neurosci 27:8967-8977.

Cepeda C, Colwell CS, Itri JN, Chandler SH, Levine MS (1998) Dopaminergic modulation of NMDA-induced whole cell currents in neostriatal neurons in slices: contribution of calcium conductances. J Neurophysiol 79:82-94.

Chan CS, Shigemoto R, Mercer JN, Surmeier DJ (2004) HCN2 and HCN1 channels govern the regularity of autonomous pacemaking and synaptic resetting in globus pallidus neurons. J Neurosci 24:9921-9932.

Coetzee WA, Amarillo Y, Chiu J, Chow A, Lau D, McCormack T, Moreno H, Nadal MS, Ozaita A, Pountney D, Saganich M, Vega-Saenz de Miera E, Rudy B (1999) Molecular diversity of K+ channels. Ann N Y Acad Sci 868:233-285.

Day M, Wang Z, Ding J, An X, Ingham CA, Shering AF, Wokosin D, Ilijic E, Sun Z, Sampson AR, Mugnaini E, Deutch AY, Sesack SR, Arbuthnott GW, Surmeier DJ (2006) Selective elimination of glutamatergic synapses on striatopallidal neurons in Parkinson disease models. Nat Neurosci 9:251-259.

Galarraga E, Hernández-López S, Reyes A, Miranda I, Bermudez-Rattoni F, Vilchis C, Bargas J (1999) Cholinergic modulation of neostriatal output: a functional antagonism between different types of muscarinic receptors. J Neurosci 19:3629-3638.

Gerfen CR, Keefe KA, Steiner H (1998) Dopamine-mediated gene regulation in the striatum. Adv Pharmacol 42:670-673.

Gertler TS, Chan CS, Surmeier DJ (2008) Dichotomous anatomical properties of adult striatal medium spiny neurons. J Neurosci 28:10814-10824.

Gong S, Zheng C, Doughty ML, Losos K, Didkovsky N, Schambra UB, Nowak NJ, Joyner A, Leblanc G, Hatten ME, Heintz N (2003) A gene expression atlas of the central nervous system based on bacterial artificial chromosomes. Nature 425:917-925.

Harvey AL (2001) Twenty years of dendrotoxins. Toxicon 39:15-26.

Hernández-López S, Bargas J, Surmeier DJ, Reyes A, Galarraga E (1997) D1 receptor activation enhances evoked discharge in neostriatal medium spiny neurons by modulating an L-type $\mathrm{Ca}^{2+}$ conductance. J Neurosci 17:3334-3342.

Hernández-López S, Tkatch T, Perez-Garci E, Galarraga E, Bargas J, Hamm $\mathrm{H}$, Surmeier DJ (2000) $\mathrm{D}_{2}$ dopamine receptors in striatal medium spiny neurons reduce L-type $\mathrm{Ca}^{2+}$ currents and excitability via a novel PLC $\beta 1-$ $\mathrm{IP}_{3}$-calcineurin-signaling cascade. J Neurosci 20:8987-8995.

Hersch SM, Gutekunst CA, Rees HD, Heilman CJ, Levey AI (1994) Distribution of $\mathrm{m} 1-\mathrm{m} 4$ muscarinic receptor proteins in the rat striatum: light and electron microscopic immunocytochemistry using subtype-specific antibodies. J Neurosci 14:3351-3363.

Hersch SM, Ciliax BJ, Gutekunst CA, Rees HD, Heilman CJ, Yung KK, Bolam JP, Ince E, Yi H, Levey AI (1995) Electron microscopic analysis of D1 and D2 dopamine receptor proteins in the dorsal striatum and their synaptic relationships with motor corticostriatal afferents. J Neurosci 15:5222-5237.

Hines ML, Carnevale NT (1997) The NEURON simulation environment. Neural Comput 9:1179-1209.

Hines ML, Carnevale NT (2001) NEURON: a tool for neuroscientists. Neuroscientist 7:123-135.

Hoffman DA, Johnston D (1998) Downregulation of transient $\mathrm{K}^{+}$channels in dendrites of hippocampal CA1 pyramidal neurons by activation of PKA and PKC. J Neurosci 18:3521-3528.

Hoffman DA, Magee JC, Colbert CM, Johnston D (1997) K+ channel regulation of signal propagation in dendrites of hippocampal pyramidal neurons. Nature 387:869-875.

Howe AR, Surmeier DJ (1995) Muscarinic receptors modulate N-, P-, and L-type $\mathrm{Ca}^{2+}$ currents in rat striatal neurons through parallel pathways. J Neurosci 15:458-469.

Johnston D, Hoffman DA, Magee JC, Poolos NP, Watanabe S, Colbert CM, Migliore M (2000) Dendritic potassium channels in hippocampal pyramidal neurons. J Physiol 525:75-81.

Kachroo A, Orlando LR, Grandy DK, Chen JF, Young AB, Schwarzschild MA (2005) Interactions between metabotropic glutamate 5 and adenosine A2A receptors in normal and parkinsonian mice. J Neurosci 25:10414-10419.

Khaliq ZM, Gouwens NW, Raman IM (2003) The contribution of resurgent sodium current to high-frequency firing in Purkinje neurons: an experimental and modeling study. J Neurosci 23:4899-4912.

Kim J, Jung SC, Clemens AM, Petralia RS, Hoffman DA (2007) Regulation of dendritic excitability by activity-dependent trafficking of the A-type $\mathrm{K}+$ channel subunit Kv4.2 in hippocampal neurons. Neuron 54:933-947.

Kopin IJ (1993) The pharmacology of Parkinson's disease therapy: an update. Annu Rev Pharmacol Toxicol 33:467-495.

LaHoste GJ, Yu J, Marshall JF (1993) Striatal Fos expression is indicative of dopamine D1/D2 synergism and receptor supersensitivity. Proc Natl Acad Sci U S A 90:7451-7455.

Levine MS, Li Z, Cepeda C, Cromwell HC, Altemus KL (1996) Neuromodulatory actions of dopamine on synaptically-evoked neostriatal responses in slices. Synapse 24:65-78.

Magee J, Hoffman D, Colbert C, Johnston D (1998) Electrical and calcium signaling in dendrites of hippocampal pyramidal neurons. Annu Rev Physiol 60:327-346.

Mallet N, Ballion B, Le Moine C, Gonon F (2006) Cortical inputs and GABA interneurons imbalance projection neurons in the striatum of parkinsonian rats. J Neurosci 26:3875-3884.

Migliore M, Cook EP, Jaffe DB, Turner DA, Johnston D (1995) Computer simulations of morphologically reconstructed CA3 hippocampal neurons. J Neurophysiol 73:1157-1168.

Olson PA, Tkatch T, Hernandez-Lopez S, Ulrich S, Ilijic E, Mugnaini E, Zhang H, Bezprozvanny I, Surmeier DJ (2005) G-protein-coupled receptor modulation of striatal CaV1.3 L-type $\mathrm{Ca}^{2+}$ channels is dependent on a Shank-binding domain. J Neurosci 25:1050-1062.

Prüss H, Derst C, Lommel R, Veh RW (2005) Differential distribution of individual subunits of strongly inwardly rectifying potassium channels (Kir2 family) in rat brain. Brain Res Mol Brain Res 139:63-79.

Schaefer AT, Larkum ME, Sakmann B, Roth A (2003) Coincidence detection in pyramidal neurons is tuned by their dendritic branching pattern. J Neurophysiol 89:3143-3154.

Segal M, Greenberger V, Korkotian E (2003) Formation of dendritic spines in cultured striatal neurons depends on excitatory afferent activity. Eur J Neurosci 17:2573-2585.

Shen W, Hernandez-Lopez S, Tkatch T, Held JE, Surmeier DJ (2004) Kv1.2containing $\mathrm{K}+$ channels regulate subthreshold excitability of striatal medium spiny neurons. J Neurophysiol 91:1337-1349.

Shen W, Hamilton SE, Nathanson NM, Surmeier DJ (2005) Cholinergic suppression of KCNQ channel currents enhances excitability of striatal medium spiny neurons. J Neurosci 25:7449-7458.

Shen W, Tian X, Day M, Ulrich S, Tkatch T, Nathanson NM, Surmeier DJ (2007) Cholinergic modulation of Kir2 channels selectively elevates dendritic excitability in striatopallidal neurons. Nat Neurosci 10:1458-1466.

Spruston N, Schiller Y, Stuart G, Sakmann B (1995) Activity-dependent action potential invasion and calcium influx into hippocampal CA1 dendrites. Science 268:297-300.

Stuart G, Schiller J, Sakmann B (1997) Action potential initiation and propagation in rat neocortical pyramidal neurons. J Physiol 505:617-632.

Stuart GJ, Sakmann B (1994) Active propagation of somatic action potentials into neocortical pyramidal cell dendrites. Nature 367:69-72.

Surmeier DJ, Bargas J, Hemmings HC Jr, Nairn AC, Greengard P (1995) Modulation of calcium currents by a D1 dopaminergic protein kinase/ phosphatase cascade in rat neostriatal neurons. Neuron 14:385-397. 
Surmeier DJ, Ding J, Day M, Wang Z, Shen W (2007) D1 and D2 dopaminereceptor modulation of striatal glutamatergic signaling in striatal medium spiny neurons. Trends Neurosci 30:228-235.

Tkatch T, Baranauskas G, Surmeier DJ (2000) Kv4.2 mRNA abundance and A-type $\mathrm{K}^{+}$current amplitude are linearly related in basal ganglia and basal forebrain neurons. J Neurosci 20:579-588.

Vetter P, Roth A, Häusser M (2001) Propagation of action potentials in dendrites depends on dendritic morphology. J Neurophysiol 85:926-937.

Wang J, Chen S, Nolan MF, Siegelbaum SA (2002) Activity-dependent regulation of HCN pacemaker channels by cyclic AMP: signaling through dynamic allosteric coupling. Neuron 36:451-461.

Wilson CJ (1992) Single neuron computation. San Diego: Academic.

Wilson CJ, Kawaguchi Y (1996) The origins of two-state spontaneous mem- brane potential fluctuations of neostriatal spiny neurons. J Neurosci 16:2397-2410.

Wilson CJ, Groves PM, Kitai ST, Linder JC (1983) Three-dimensional structure of dendritic spines in the rat neostriatum. J Neurosci 3:383-388.

Yan Z, Flores-Hernandez J, Surmeier DJ (2001) Coordinated expression of muscarinic receptor messenger RNAs in striatal medium spiny neurons. Neuroscience 103:1017-1024.

Yuan LL, Adams JP, Swank M, Sweatt JD, Johnston D (2002) Protein kinase modulation of dendritic $\mathrm{K}^{+}$channels in hippocampus involves a mitogen-activated protein kinase pathway. J Neurosci 22:4860-4868.

Zhang H, Maximov A, Fu Y, Xu F, Tang TS, Tkatch T, Surmeier DJ, Bezprozvanny I (2005) Association of CaV1.3 L-type calcium channels with Shank. J Neurosci 25:1037-1049. 